Eskişehir Osmangazi Üniversitesi

Sosyal Bilimler Dergisi

Aralık 2019, 20(2), 158-189

DOI: 10.17494/ogusbd.672762

\title{
Yetenek Yönetimi Uygulamaları Ölçeği Geçerlilik ve Güvenilirlik Çalışması
}

\author{
Cengiz DURAN, Dursun BOZ, Sema BEHDiOĞLU, Songül KUTLU*
}

Yetenek Yönetimi Uygulamaları Ölçeği Geçerlilik ve Güvenilirlik Çalışması

\section{Özet}

$\mathrm{Bu}$ araştırmanın amacı, yetenek yönetimi uygulamaları konusunda kapsayıc bir ölçek geliştirmektir. Taslak ölçeğin geliştirilmesinde ilgili literatür incelenip 64 ifade ile madde havuzu oluşturulmuştur. illk pilot uygulama 4 işletmedeki 200 çalışan ile yapılmışır. Teorik olarak faktörleşmeyen ve faktör yükleri düşük ifadeler $(9,10,14,17,19,27,29,55,58$ ve 59$)$ çıkarılarak 54 ifade ile 500 çalışana uygulanmıştır. İkinci pilot çalışmada teorik olarak faktörleşmeyen ve faktör yükleri düşük ifadeler (1,11,18,28 ve 57) çıkartılmışıı. Nihai ölçek elde edilen 49 ifade ile 1182 çalışana uygulanmıştır. Bulgularla Yetenek Yönetimi Uygulamaları ölçeğinin 7 faktörlü yapısının "1.Ödüllendirme”, "2.Elde Tutma”, "3.Eğitim", "4.Elde Tutma ve Bağllık", "5.Cezbetme", "6.Yetenek Havuzu" ve "7.SeçmeYerleştirme" olarak adlandırıması uygun bulunmuştur. Keşfedici faktör analizinin ardından Yapısal Eşitlik Modellemesi ile doğrulayıcı faktör analizi yapılan ölçeğin Cronbach's Alpha katsayısı 0,958 olduğu belirlenmiştir.

Anahtar Kelimeler: Yetenek Yönetimi, İnsan Kaynakları Uygulamaları, Ölçek Geliştirme
Talent Management Applications Scale Validity and Reliability Work

Abstract

The aim of this research is to develop inclusive a scale in talent management. In the development of the draft scale, the relevant literature has been examined and a pool of 64 expressions has been formed. The first pilot application was carried out with 200 employees in 4 enterprises. Theoretically, non-factorizing and low factor loadings items $(9,10,14,17,19,27,29,55,58$ and 59) were removed and applied to 500 employees with 54 expressions. In the second pilot study, theoretically, nonfactorizing and low factor loadings (1, 11, 18, 28 and 57) were excluded. The final scale was applied to 1182 employees with 49 expressions. Obtained from the findings of the 7-factor structure of the talent management scale named by working team "1.Rewarding", "2.Keep employee", "3.Education", "4.Loyalty", "5.Attraction", "6.Talent pool" and "7.Selection placement". After exploratory Factor Analysis, Cronbach's alpha coefficient was 0.958 of the scale with structural equation modeling and confirmatory factor analysis.

Key Words: Talent Management, Human Resources Applications, Scale Development

\section{Giriş}

Günümüzde meydana gelen hızlı değişimler, tüm dünyayı etkilerken işletmeleri de yakından ilgilendirmektedir. İşletmeler değişimlerle birlikte yoğun rekabet ortamında hayatlarını sürdüre-

${ }^{*}$ Cengiz DURAN, Doç.Dr., Dumlupınar Üniversitesi, İşletme Bölümü, cengizduran@dpu.edu.tr, ORCID ID orcid.org / 0000-0001-7910-0677; Dursun BOZ, Dr., Dumlupınar Üniversitesi, İşletme Bölümü, dursunboz@hotmail.com, ORCID ID orcid.org / 0000-0003-3206-8950; Sema BEHDiOĞLU, Prof.Dr., Dumlupınar Üniversitesi, Ekonometri Bölümü, sema.behdioglu@dpu.edu.tr, ORCID ID orcid.org / 0000-0002-4759-2088; Songül KUTLU, Dr., Dumlupınar Üniversitesi, İşletme Bölümü, snglkutlu@hotmail.com, ORCID ID orcid.org / 0000-0003-2801-129X 
bilmek için gelişmeleri yakından takip etmeli ve değişimlere ayak uydurabilmelidirler. İşletmelerin yoğun rekabet ortamında başarıı olabilmeleri için insan kaynağı faktörüne ihtiyaçları vardır. İnsan kaynağı faktörünün ayırt edici özelliği olan yetenekli bireylere sahip olmak ise temel ihtiyaç haline gelmiştir. Yeteneklerin belirgin gücünden yararlanamayan işletmeler, küreselleşen iş dünyasında ve yoğun rekabet ortamında varlıklarını sürdürecek cesareti bulamayabilirler. Çünkü hızlı değişimler yenilik yapmayı kaçınılmaz kılar ve yenilik yapma cesareti yetenekli insan kaynağıyla mümkün olabilir. Bu fikirlerden yola çıkarak insan kaynağı yönetimine yeni rol ve sorumluluklar yüklenmiştir. İşletmeler insan kaynaklarını yönetmenin yanında yetenekli çalışanları yönetebilmelidirler. İçinde bulunduğumuz yüzyılda teknolojinin hızla ilerlemesi, iletişim araçları gelişmesi ve bunların sonuçları küreselleşmeyi gündeme getirmiştir. Hızla artan teknolojik yenilikler ve küreselleşme hem yerel hem de uluslararası rekabette işletmelerin yeni değerlere sahip olmalarını elzem kılmıştır. Bu değerler yeri kolayca doldurulamayan ve kopyalanamayan değerler olarak işletmelerin temel gereksinimine dönüşmüştür. Bu bağlamda işletmelerin temel gereksinimleri yetenekli çalışanları bünyelerinde barındırmak olmuştur. Yetenekli çalışanları işletme bünyesinde barındırmak literatüre "yetenek savaşları" adıyla girmiştir. Potansiyelli yüksek çalışanların keşfedilmesi, işletmeye kazandırılması, işletme hedefleri doğrultusunda eğitilip yetiştirilmeleri sürdürülebilir rekabette işletmeleri bir adım ileriye taşımıştır. Günümüzde insan kaynakları uygulamalarının işletme ihtiyaçlarına yetersiz kalması, yönetime yeni amaç ve roller yüklenmesiyle Yetenek Yönetiminin gelişimini sağlamış ve işletme literatürüne yeni bir yaklaşım olarak eklemlenmiştir. Bu yaklaşım çalışmamızda öncelikle yönetim kavramının yetenek yönetimine kadar olan gelişim aşamaları, yetenek yönetimi ile ilgili kavramlar ve yetenek yönetimi unsurları ele alınarak yetenek yönetimi konusunda daha kapsayıcı bir ölçek geliştirmek amaçlanmıştır. Bu amaçla alanyazında nitel çalışmalar olmasına rağmen az sayıda nicel bir çalışmaya rastlanılmıştır. Bu nedenle alanyazında var olan nitel çalışmalar incelenerek daha kapsayıcı nicel bir çalışmanın gerekli olduğu değerlendirilmiştir. Nitel çalışmalar ayrıntılı bilgiler toplayarak araştırmaya yön vermemizi sağlarken nicel çalışmalar sayı ve rakamlara dayanarak istatistiksel analizler yapmamıza olanak sağlamaktadır. Bu bağlamda Yetenek Yönetimi Uygulamaları ölçeği alanyazındaki daha kapsayıcı nicel çalışma boşluğunu doldurması beklenmektedir. Bu boşluğun doldurulmasında nitel çalışmalardan yola çıkılarak Yetenek Yönetimi Uygulamaları ifadeleri için madde havuzu 5 noktalı Likert tipinde oluşturulmuştur. Bu ifadeler 2 adet pilot ve nihai çalışmayla ardışık zaman serilerinde Şanlıurfa Organize Sanayi Bölgesindeki 4 ayrı işletmenin 1182 çalışanı ile yapıımıştır. Çalışmanın teorik kısmında Yetenek Yönetimine geçiş aşamaları, Yetenek ve Örgütsel Bağlamda Yetenek Kavramı, Yetenek Yönetimi ve Yetenek Yönetiminin alt faktörleri irdelenmiştir. Uygulama kısmında ise güvenilirlik analizi, geçerlilik analizi, örneklem yeterlilik testi, faktör analizi, yamaç eğim grafiği ve modelin uyum endeksi değerlerine yer verilmiştir.

\section{Yetenek Yönetimi}

\subsection{Yetenek Yönetimine Geçiş Aşamaları}

Illk olarak personel yönetimiyle başlayan sonraları İnsan Kaynakları Yönetimi adını alan bu aşamalar Stratejik Insan Kaynakları Yönetimi, Yetkinlik Bazlı İnsan Kaynakları ve son kertede Yetenek Yönetimi uygulamalarıdır. İnsan Kaynakları Yönetimi (IKY) kurum ve organizasyonların, örgüt- 


\section{Cengiz DURAN | Dursun BOZ | Sema BEHDiOĞLU | Songül KUTLU}

sel hedeflerine etkin ve verimli bir biçimde ulaşabilmek amacıyla gerçekleştirilen faaliyetleri şeklinde tanımlanabilir (Jackson vd., 1989:207). Bu faaliyetlerde organizasyonun insan kaynağının yönlendirilmesini sağlayan tüm girişimleri İnsan Kaynakları Yönetimi'ni oluşturmaktadır (Lloyd ve Leslie,1997). Başka bir tanımlamada ise İnsan Kaynakları Yönetimi, organizasyonda amaçlanan değerler temelinde, gerekli olan insan kaynağının en iyi şekilde temini, motivasyonu, gelişimi, bunların sonucunda ödüllendirilmesi ve sürgit kılmayı sağlamak maksadıyla meydana getirilen plan, program ve stratejilerin hayata geçirilmesidir (Tanke, 1990:5). Bu stratejilerin hayata geçirilmesi ve organizasyonların amaçlarına ulaşmasında gerekli tüm faaliyetleri yerine getirecek gerekli sayıda çalışan istihdam, eğitim, geliştirilme ve değerlendirilmesi amaçlanır (Boone ve Kurtz, 1998: 266).

IKY'nin doğuşu temelde 1950'lerdeki Japon işletmelerin üretimine fazlaca nitelik kazandıran ve buradan tüm dünyaya yayılan Toplam Kalite yaklaşımıdır. Bu anlayış 1960-70'lerde Batı dünyasında akademik olarak tanınmaya başlamış ve ABD'de ders olarak (Brewster, 1994) verilmeye başlanmasıyla dünya genelinde İnsan Kaynakları Yönetimi tanınmıştır. Bu tanınma sonucunda Personel Yönetimi yaklaşımını da sonlandırmıştır. (Ertürk, 2009: 303). İnsan Kaynakları Yönetimi uygulamaları genel olarak; ihtiyaçlar doğrultusunda iş analizleri, nitelikli çalışan özelliklerinin tespiti, bu özelliklere uyum gösterenlerin seçim aşamaları, işe yerleştirilmesi, yönlendirilmesi, eğitilmesi, kariyer planı yapılması, performans değerlendirmesi, ücretlendirme, ödüllendirme ve bağlılıklarının geliştirilmesini kapsamaktadır (Fındıkçı, 1999; Armstrong, 2006).

IKY ile stratejik insan kaynă̆ını planlama, teknolojik ilerlemeleri takip etme ve bireylerde oluşan bilgilerin eskimesini önlenmesiyle çalışanların sürekli olarak gelişmelerini sağlamak amaçlanır. Organizasyon içerisinde kişisel ilişkilerden ziyade bütünsel ilişkileri incelemek ve örgütün bu yönde gelişip ilerlemesini sağlamak İnsan Kaynakları Yönetiminin temel işlevleri arasındadır (Fındıkçı, 1999:15-21). IKY aynı zamanda işletmelerin plan ve stratejilerini hayata geçirmek gayesiyle işletme gereksinimlerini karşılamak için uygun sayıda vasıflı çalışanın işletmeye çekilmesi, işe alınmaları, eğitilmeleri, geliştirilmeleri, motivasyonlarının artırıması, çalışan bağılığının kazanılması ve belli zaman dilimlerinde değerlendirilmesidir (Kasımov, 2006:6; Bingöl, 1998:3-4). İşletmelerde IKY uygulamalarının bir nedeni de stratejik nitelik kazanması ve rekabet avantajı sağlamasından ileri gelir (Boxall, 1996:59). İKY sistemlerini çalışan tutum ve davranışları ile onların örgüt hakkındaki düşüncelerini etkilemesi nedeniyle örgütsel değerleri bir arada tutan 'tutkal' gibi algılanması gerekir. Herhangi bir rekabet avantajı elde etmek çalışanların çabalarıyla sağlanacağı için buna uygun yaklaşıma stratejik yaklaşım benimsenmesi, örgütsel değerleri ve amaçları desteklemesi, örgütün amaçlarına etkili biçimde ulaşılmasının sağlanması IKY ilkelerinin özünü ifade eder (Ferris vd., 1999:385; Özdemir, 2010:23).

\subsection{Yetenek ve Örgütsel Bağlamda Yetenek Kavramı}

Türk Dil Kurumu Büyük Türkçe Sözlüğünde yetenek; "bir kimsenin bir şeyi anlama veya yapabilme niteliği, kabiliyet, istidat"; "bir duruma uyma konusunda organizmada bulunan ve doğuştan gelen güç, kapasite"; "kişinin kalıtıma dayanan ve öğrenmesini çerçeveleyen sınır" ve "dışarıdan 
gelen etkiyi alabilme gücü" şeklinde tanımlanmaktadır (www.tdk.gov.tr). Buckingham ve Vosburgh (2001)' göre yetenek; "Bir kişinin üretken bir şekilde tekrar edebilen düşünme, hissetme ve davranma yetilerinin uygulanabilmesidir" (Buckingham ve Vosburgh, 2001:21). Çırpan ve Şen (2010)'a göre iş hayatı açısından "yetenek" kavramı, "işletmenin kaderinde rol oynayabilecek düzeyde üstün nitelikleri olan, yönetsel ve teknik pozisyonları doldurma potansiyeline sahip geleceği parlak çalışanlar" (Çırpan ve Şen, 2009: 110) olarak ifade edilmektedir. En temel anlamda yetenek, özel beceri ve yetiler anlamında kullanılmaktadır. Yetenek kavramı birçok özelliği içerisinde barındıran geniş spektrumlu bir kavramdır. Akar (2012)'ye göre yeteneğin bir takım genel özellikleri; doğuştan gelmesi, özel olarak tanımlanabilen üst düzey kabiliyetler, kişiye özgü beceriler, kişiyi ustalık seviyesine taşıyacak kuvvetli bir edim, performansı pozitif etkileyen, geliştirilebilen ve genişletilebilen bir kavramdır.

Yetenek kavramı tanımlanırken daha ziyade bireysel anlamda ele alınarak örgütsel süreçler açısından önemi vurgulanır. Örgütsel açıdan yetenek kavramı stratejik, finansal, teknolojik dönüşüm süreçlerini uygulayabilmek, bu kavramları örgüt iklimine adapte edebilmek ve örgüt amaç ve hedeflerine ilişkin sürdürülebilirliğini sağlamak için kullanılan önemli bir kaynaktır (Ulrich, 1997:171). Örgütsel yetenek kavramı tarihsel süreçte gelişerek bir örgütün fiziksel faaliyetlerinin ve özellikle orta ve üst düzey yöneticilerinin kabiliyetlerinin toplamıdır (Matsusaka, 2001:414). Örgütsel yetenekler, genel olarak, örgütlerin kontrol ettikleri ve varlıklarından maksimum şekilde yararlanabilmelerini sağlayan bilgi, beceri ve tecrübelerinin tümü olarak tanımlanabilmektedir (Song vd., 2007:147). Örgütsel yetenekler, örgütlerin karar verme ve uygulama süreçlerinde iç çevresine odaklanarak, dış rekabet koşullarına adapte olabilmeleri ve rekabet avantajı sağlayabilmeleri için kullanılan kolektif alışkanlıklardır (Ulrich, 1997:171). Bu avantajı elde etmede örgütlerin girişimlerin ne şekilde yürütüleceğini ve stratejik açıdan etkinlik sağlayacak olan iş süreçlerinin tamamı olarak ele alınmalıdır. Bu süreçlerde örgütsel yetenekler tek bir sektörde değil birden çok farklı sektörde uygulanabilecek yeteneklerdir (Matsusaka, 2001:414).

\subsection{Yetenek Yönetimi (YY)}

İşletmelerin çalışanlarına yönelik uygulamalarının ilk evresi personel yönetimi ile başlamıştır. Personel yönetimi işletmeye "yönetim" kavramını kazandırmış ve işe alım, işten çıkarma, çalışan kayıtlarının tutulması gibi işlemlerin yapılmasını sağlamıştır. Personel Yönetimi, günümüz yönetim düşüncesine nazaran sınılı işlevleri kapsamaktaydı ve stratejik rolleri kapsamamaktaydı. 1970'lerin son çeyreğinde ve 1980'li yılların başlarında İnsan Kaynakları Yönetimi kavramı kullanıımaya başlanmış ve IKY'nın, bu aşamadaki fonksiyonu "operasyonel” seviyede idi. Takip eden aşamada, "insan" faktörünün örgütsel performanstaki pozitif etkisi anlaşılmış ve üst düzey yönetiminde IKY'ye verilen değer artmaya başlamıştır. IKY'nin bu evredeki rolü "iş ortağı" olmuş ve çalışanlara yönelik uygulanan politikalarda, iş stratejilerinin geliştirilmesinde, politikaların en iyi şekilde uygulanmasında etkin hale gelmiştir (Morton, 2005: 13). 


\section{Cengiz DURAN | Dursun BOZ | Sema BEHDiOĞLU | Songül KUTLU}

IKY'deki değişimler gelişimler küresel boyutlara ulaşmaya başlayınca kavram "yönetsel” seviyeye gelmiştir. Örgütlerin büyümesi, teknolojik gelişmeler ulusal ve uluslararası rekabetin hız kazanmasıyla İKY yeni bir görev üstlenmiş ve "stratejik" karar almada etkili olmuştur. íKY işletme stratejilerini destekleyen ve bu stratejileri alt fonksiyon stratejileriyle uyumlu hale getiren, çalışanların yetenek ve yetkinliklerini keşfedip geliştirerek işletmeyi günün şartlarına ve taşıdığı misyonuyla günün ötesi şartlara hazırlayan bir kuruluş haline getirmeyi hedeflemiştir. IKY uygulamalarıyla sadece yönetsel anlamda değil kavramsal anlamda da gelişmeleri beraberinde getirmiştir. Başlangıçta IKY, Stratejik IKY, yaşanan gelişmeler ve küresel faktörlerle birlikte Yetkinliklere Dayalı íKY (YDIKY) ve son olarak da Yetenek Yönetimi (YY) şeklini almıştır. İKY'nin Yetenek Yönetimine kadar değişen rolleri ve gelişim evreleri Şekil'de sunulmuştur.

Şekil 1: IKY'nin Gelişim ve Değişen Rolleri

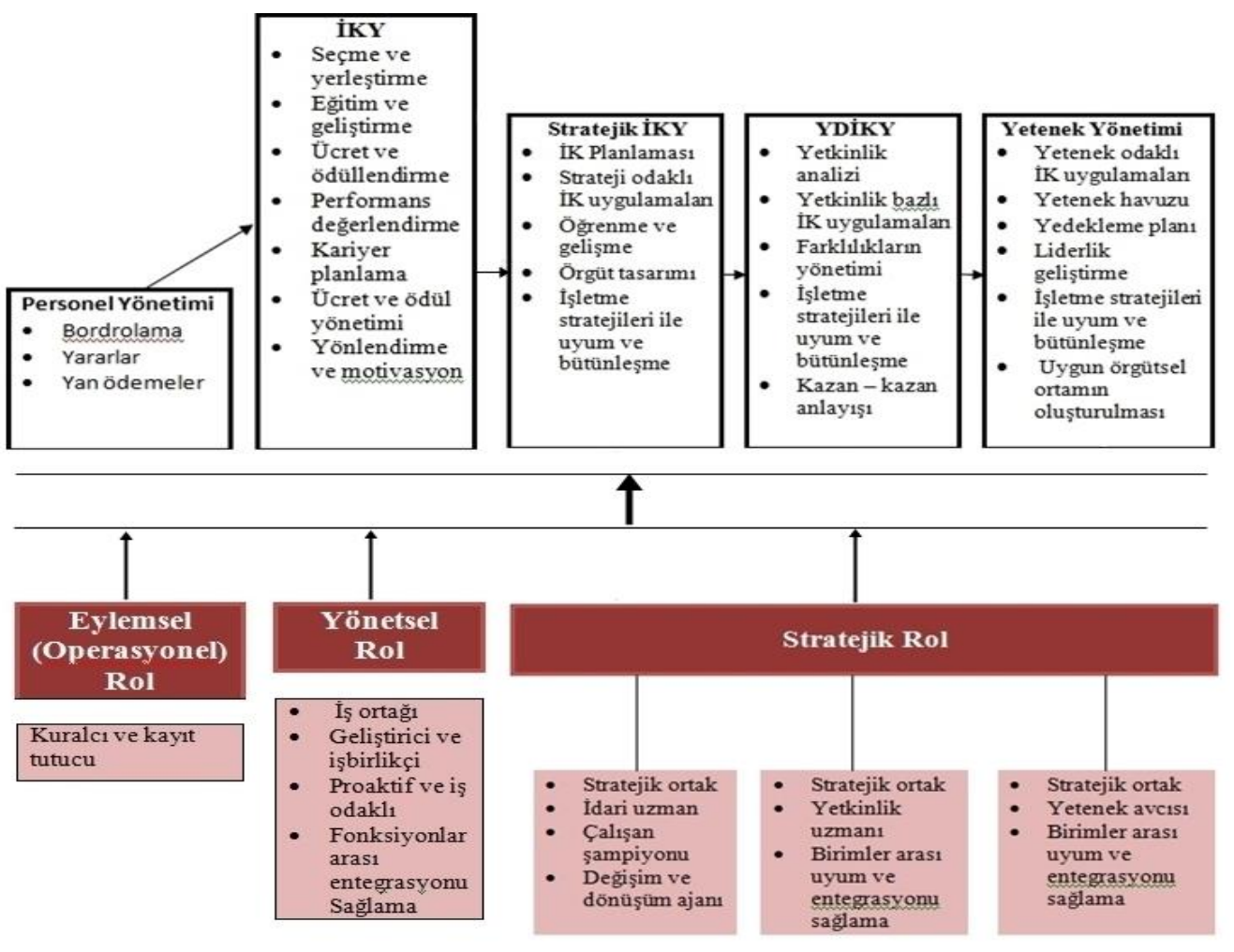

Kaynak: Alayoğlu, 2010:75.

Değişen rolleri sayesinde Yetenek Yönetimi; iş gücü planlamak, yetenek çatışma analizi, işe alma süreci, eğitim ve geliştirme faaliyetleri, elde tutma faaliyetleri, yetenek özetleri ve yedekleme plan- 
larının kapsadığı stratejik bir bütünlük şeklinde tanımlanabilir (McCauley ve Wakefield, 2006:4). Yetenek yönetimiyle bağlantılı olarak gerek araştırmacılar gerekse uygulayıcılar tarafından ortaya atılmış birçok tanım mevcuttur. Bu tanımlamaların yanı sıra yetenek yönetimine ilişkin genel kabul görmüş bir tanımlama olmadığı bilinmektedir (Ashton ve Morton, 2005:30). Yetenek yönetimi tanımları konuya ilişkin bilim dallarının bakış açılarına göre farklılaşmaktadır. Bu farklııkların temelinde tanımlamaların bir kısmının uygulayıcılar diğer bir kısmının ise araştırmacılar tarafından yapılmasıdır. Yetenek yönetimine ilişkin yapılmış olan bazı tanımlamalar ve yazarları şunlardır;

- Yetenek yönetimi; tüm insan kaynakları süreçlerini, idaresini ve teknolojilerini kapsamayan işe almak, geliştirmek ve iş gücü yönetim sürecinin bağlantı noktasında olan yetenek optimizasyonudur (Schweyer, 2004: 38).

- Yetenek yönetimi, örgütsel intiyaçların doğrultusunda doğru çalışanın doğru zamanda ve doğru işte, doğru uygulamaların yapılmasını sağlamaya yönelik olan bir süreçtir (Mucha, 2004: 99).

- Yetenek yönetimi; işletmedeki tüm bölüm yöneticileri arasındaki işbirliğini ve iletişimi sağlayan; işgücü planlaması, işgücü alımı, personel eğitimi ve geliştirilmesi, yeteneklerin performanslarının takibi ve başarı planlaması; performans değerlendirme süreçleri gibi çok farklı aşamaları olan ve örgütlerin mecburi olarak uygulamaya başladıkları bir yaklaşımdır (McCauley ve Wakefield, 2006:4).

Yapılan tanımlamalarda görüldügü üzere YY sürecine ait tüm uygulamalar, örgütün stratejileri ve hedefleriyle birleşip bütünleştiği zaman başarıyla işleyecektir. Yetenek yönetimi örgütler açısından rekabet avantajı sağlayacak önemli bir süreç olduğunu söylemek mümkündür. Ancak örgütler için önemli bir rekabet unsuru olabilecek bu sürecin çok da kolay yönetilen ve uygulanabilen bir süreç olduğunu söylemek mümkün değildir. Temelinde insan olan bu sürecin yönetilmesi oldukça zordur ancak mümkündür (Redford, 2005:20).

Yetenek Yönetiminde esas nokta, yeteneklerin analiz edilmesi, anlaşılması, biçimlendirilmesi doğru ve etkin oluşturulmuş süreçler ve programlar aracılığı ile disipliner süreçlerle etkin ve doğru şekilde yönetilmesidir. Yetenek yönetimine öncüllerine ilişkin bakış açıları 5 ayrı (süreç, kültürel, rekabetçi, gelişim ve değişim) perspektifle açıklanabilir. Süreç perspektifi örgütsel yetenekleri yüksek çalışanlara kariyer planlamasını içermelidir. Kültürel perspektif çalışanların zihinsel yapılandırılmasının yeni fikirleri ortaya çıkaracak ve geliştirecek fırsatların tanınmasıdır. Rekabetçi perspektif çalışanların yeteneklerinin geliştirilmesinin en faydalı yatırım olması ve çalışanların elde tutulmasını içermelidir. Gelişim perspektifi işletme amaçlarına uygun hareket eden çalışanların kariyer olanakları, cezp edilmesi, uygun işlerde çalıştırılmasıdır. Değişim perspektifi ise örgütsel değişimi kıvılcım olarak kabul edip yeteneklerin örgütsel kültür, liderlik ve yönetimsel kabiliyetlerini taşımasıdır (Sivenko, 2008). Kumudha ve Senthilkumar (2012: 7883) çalışmasında yetenek yönetiminin öncüllerinin yedi adımda gerçekleştirilebileceğini ileri sürmüştür. Birinci adım, yeteneğin tanımlanması ve örgütsel ihtiyaçlarla bağdaştırımasıdır. İkinci adım, değerlendirme sonuçlarıyla yetenek matrisinin oluşturulmasıdır. Üçüncü adım, örgütsel hedeflerin güçlü ve zayıf yönlerinin yetenekli çalışanlarla 


\section{Cengiz DURAN | Dursun BOZ | Sema BEHDiOĞLU | Songül KUTLU}

uygunlaştırılmasıdır. Dördüncü adım, bireysel gelişim planlarının belirlenmesidir. Beşinci adım, örgütsel planların uygulanmasında üst yönetimle departman sorumluları arasında belgelendirilmesidir. Altıncı adım, çalışanların kişisel gelişim sorumluluğunu üstlenmesidir. Yedinci adım ise yetenek yöneticisinin her kademede belirli periyotlarla değerlendirmelerde bulunmasıdır.

Yetenek Yönetiminin beklenen ardılları şöyle özetlenebilir; Örgütsel yapı taşlarının ve örgütsel iş süreçlerinde iyileşme, Üretilen ürün ve hizmetin pazar payında artış, Rekabette başarıyı yakalayacak değerlere sahip olunması ve sürdürülebilirliğin sağlanması, Örgütsel yeteneklerin geliştirilmesiyle örgüt genelinde stratejik koordinasyondur (Bayramoğlu, 2007: 27). Yeni Yönetimi uygulayan işletmelerde, diğer işletmelere göre fark yaratacak yetenekli çalışanlar sayesinde, sahip olunan değerlerin iyi yönetilmesi, eğitim ve gelişimlerine gerekli özen gösterildiğinde, başarı sağlanarak rekabette üstünlük sağlayacak, bu konu ile ilgili yapılacak yatırım ise en doğru ve kârlı yatırım olacaktır (Altınöz, 2018:94). Bu yatırım sayesinde işletmeler rekabet avantajı ve sürdürülebilirliklerini artırarak fark yaratacak, yenilikçi, rekabet üstünlügünü sağlayacak olanların yetenekli çalışanların olduğunu fark eden yöneticiler yetenek yönetimini iyi bir şekilde yürütmeyi öncelikleri haline getirirler. Yetenek yönetiminde yetenekli çalışanların kuruma çekilmesiyle kalmayıp, onları elde tutup gelişimlerini sağlamak ve yetenek yaklaşımını en tepe kademeden en alt kademeye kadar özümsenir hale getirmek, yetenek yönetimi uygulamasının etkililiğinin sağlanması adına oldukça büyük bir önem arz etmektedir Gündüzalp ve Özan, 2018:37). Bu önem işletmelerin çalışan odaklı olmasını sağlayarak onları birer araç değil amaç olarak ele alınmalarını sağlayacaktır (Altıntaş, 2018:39).

Yetenek Yönetimine ilişkin 7 alt faktör Meyer ve Allen (1991), Fegley (2006), Özutku (2008), Ooi (2009), Alayoğlu (2010), Eryiğit (2012), Şahin (2015), Demirel ve Savaş (2017), Altınöz (2018) çalışmaları referans alınarak; Ödüllendirme, Elde Tutma, Eğitim, Elde Tutma-Bağılık, Cezbetme, Yetenek Havuzu ve Seçme-Yerleştirme olarak adlandırılması çalışma ekibince uygun bulunmuştur.

\subsection{1. Ödüllendirme}

Yeteneğin elde tutulma sürecinin kurulması ve bunun sağlıklı işletilmesi gereklidir. Elde tutmanın önemli unsurlarından biri olan ödüllendirme, gelişim fırsatları sunulması ve kariyer planlamasının yapılması süreçlerindendir. Örgütler geliştirecekleri bu yöntemler ile, hayat boyu öğrenme ve yüksek performans kültürünü sağlayabileceklerdir (Ooi, 2009: 151). Organizasyonda amaçlanan değerler ışığında, gerekli olan insan gücünü en iyi şekilde teminini, motivasyonu, geliştirilmeleri, bunların sonucunda ödüllendirilmesini ve sürgit kılmayı sağlamak maksadıyla meydana getirilen plan, program ve stratejilerin hayata geçirilmesidir (Tanke, 1990: 5).

Ihtiyacı hissedilen alanlarda yetenekli iş gören adayının örgüte çekilmesi ve katılımın sağlanması için, örgütü rakiplerinin nazarında farklı ve cazip kılacak, onu diğer örgütlerden ayıracak uygulamalara yer verilir. Bu uygulamalar içerisinde, ücret ve ödüllendirme sistemi, uygun çalışma ortamları, sosyal haklar, kariyer fırsatı, yarar paketleri vb. yer almaktadır (Alayoğlu , 2010). Yetenekli kişinin verimliliğinin üst düzeye taşınması ve örgütün içinde tutabilmek için performans değerlendirme sistemleri doğrudan eğitim ve geliştirme, ödüllendirme ve kariyer ile ilişkilendirilir (Stone, 
2002). Aslında yetenekli kişiler kendi kendilerini motive eden, başarı odaklı bir yapıya sahip olsalar da onlarında başarılarının tanınıp "takdir edilmesi" gereklidir (Atlı, 2012). Küreselleşme olgusu, çalışanlar üzerinde büyük değişimlere neden olmuştur. Başta beyaz yakalıların iş yaşamına ve örgütlere bakışları değişmiştir. Bu yönüyle çalışanların örgüte güveni, işlerine adanmışlıkları, bağ|ılık düzeyleri azalmıştır. Azalan bu değerlerin yerine daha çok güven duymak, takdir görmek, yeteneklerini anlamlandırmak ve hayata geçirebilmek, beklentilerini karşılamak, iş yaşam dengesi gözetmek, yüksek maddi ve manevi ödüller gibi bireysel beklentiler öne çıkarmak, insani yönlerinin görülüp fark edilmesine önem vermektir (Akar, 2012:48).

Eğer işletmeler yeteneklerin işe alınması, eğitimi ve gelişiminde çok fazla çaba, zaman ve para harcamışlar ise bu yetenekleri elde tutmak istemektedirler. Bunun yapabilmesi için sadece gözle görülebilen değil, görülmeyen ödüller de önemli rol oynar (Born ve Heers, 2009:6). Yetenekli insanlar piyasa standartları dahilinde ücretlendirilme isterler. Ayrıca, performanslarından dolayı ya parasal ya da başka bir şekilde ödüllendirilme isterler (Hatum, 2010: 103). Bu nedenle, işletmede çalışanların yaptıkları ve yapmaları beklenilen katkılarla uyumlu bir ödüllendirme sistemi oluşturmak önemlidir (Russo, 2010: 61). Inskeep ve Hall (2010) çalışmasında iyi ücretle çalışanların bile ayrılmayı isterken işletmelerin çalışmayı nasıl çekici hale getireceğini, coğrafi olarak dağılmış ve elektronik olarak bağlantılı olan bir dünyada çalışmakta olan farklıık arz eden bir iş gücünü nasıl çekileceğini, nasıl elde tutulacağını, motive edilmesini, takdir edilmesini, ödüllendirilmesini, yetenekli kişileri çeken ve elde tutan değerli ve iyi yönetilen ödül ve takdir etme sistemlerini nasıl yönetileceğini, onların bilgilerini nasıl geliştirip paylaşılabileceğini, belirli davranış ve eylemleri sergilemeye devam etmeleri için nasıl motive edileceğinin sorgulanması ve bu sorulara yanıt verilebilmesinin gerekliliğini vurgulamaktadır.

\subsubsection{Elde Tutma}

Günümüzde devamlı artan küresel rekabet, değişen pazarlar ve beklenmedik durumlar ile karşı karşıya kalınmakta ve işletmeler ihtiyaç duydukları yetenekli çalışanların istihdam edilme, elde tutulma ve geliştirilmesi gitgide zorlaşmaktadır (McCauley ve Wakefield, 2006:4). Çalışanın elde tutulması örgüt için kritik öneme sahip iş görenleri kaybetmemek için gösterilen faaliyetlerin toplamı olarak nitelendirilir (Hedberg ve Helenius, 2007:179).

Örgütler, küresel rekabet karşısında üstünlüğü elde etmek ve sürdürmek için yetenekli kişileri cezbetmesi kadar elindeki yetenekli kişileri de kaybetmemeyi başarması gereklidir. Yetenekli iş görenin örgüt içerisinde tutulması büyük ölçüde kişinin örgüte bağı olmasının sağlanması demektir. Diğer bir ifade ile elde tutma uzun vadede çalışan bağılığının sağlanmasına yönelik bir stratejidir (Özutku, 2008:80). Bu bağlamda, liderler yeteneklerin iyi yönetilmemesinin doğuracağı sonuçları ve getireceği kayıpları görebilmeli, yetenekli çalışanların işletmeye olan sadakat ve bağlılıklarını artırarak, işletmede verimlilik ve kârılı̆̆ı sağlamaları gerekmektedir (Kaye ve Evans, 2003:291).

\subsubsection{Eğitim}

1990’lı yıllardaki toplumsal ve küresel değişimler işverenlerin işletmeye bakış açılarını ve işletmelere olan tutum ve davranışlarına yönelik birçok değişime neden olmuştur. Örgüt içerisinde 


\section{Cengiz DURAN | Dursun BOZ | Sema BEHDiOĞLU | Songül KUTLU}

bulunan çalışanların ve yöneticilerin sorumluluklarını etkin bir biçimde yerine getirmede gerekli olan teknik ve davranışsal yeniliklerde aşamalı olarak değişimler görülmüştür. Bu yüzyılın en sık kullanılan sözcüğü "eğitim" (training) olmuştur. İşletme açısından bu terim; eğitim yöneticisi tarafından bir mesleği tanımlamak veya sınıf temelli bir ilerleme tekniğini tanımlamak için kullanılmaktadır. Bugünse "gelişim" ile ilintili olarak kullanılan kelime "öğrenme" olarak yerini almıştır (Erçokses, 2009:98).

Yetenek yönetimi konusunda yapılan araştırma ve çalışmalar kurs ve işletme içi eğitimlerle yetenekli çalışanların işletmeye olan güven ve bağ|lıklarında oldukça etkili olduğunu göstermiştir. Bununla birlikte; çalışanları yönlendirme, iş rotasyonları, birlikte yürütülen iş rotasyonları, ortaklaşa yürütülen proje ve çalışmalar, yürütülmesi zor olan çalışmalar gibi başka eğitim ve geliştirme çalışmalarında etkisinin kaçınılmaz gücü vurgulanmıştır (Skuza vd., 2013:462).

\subsubsection{Elde Tutma-Bağlılık}

Çalışan bağ|ı̆ı̆ı, elde tutmayla mümkün olabilir. Ancak elde tutma faaliyetleri işletmenin politikalarıyla belirlenirken bağlılık bireysel bir yaklaşımdır. Bağılık, seçenekler çok olmasına rağmen bireyin işletmede kalma isteğini, işletmeyi tercih etme isteğini ifade eder. İşletme çalışanlarını işletmeye bağlamak, iş sadakati ve çalışan memnuniyetini kazanmaktan daha ileri bir aşamadır. Bireylerin örgüt yapısından kaynaklı huzur ve rahatlığı memnuniyeti, sadakat örgüte dahil olma isteğini açıklamaktadır. Bunlardan daha ileri aşama olan bağlıık ise, bireylerin örgütü özümsemeleri, kısa ve uzun vadede örgütün tüm gelişimini takip etmeleri ve örgütün düştüğü her durumda örgüte katkı sağlayabilecek özverilerinin olmasını ifade eder (Hewitt Associates, 2008).

Örgütsel açıdan çalışan bağ|ı̆ğı literatürde farklı dönemlerde farklı çalışmalarla açıklanmıştır. Yazın tarihinin başlangıcında bağılık örgütün değer ve amaçları doğrultusunda gelişen duygusal bir bağ|ıık olarak açıklanmıştır. Araştırmalar bağlılığı, bireylerin örgüte kazandırdıkları değerler olarak tespit etmişlerdir. Daha sonraları Meyer ve Allen (1991) yaptıkları çalışmada bahsettiğimiz bağ/ıık türlerini sınıflandırmışlar ve ilk tip bağ|ı̆ğa "duygusal bağlıık", ikinci tip bağlılığa ise "devamlılık bağ|ı̆ı̆ı" adını vermiş̧lerdir. Meyer ve Allen'in açıklamalarına göre duygusal bağlılıkla bireyin duygularıyla hareket ederek işletmeye bağlanmasını, örgütle olan içselleşmesini devamlılık bağlıı̆ında ise bireylerin örgütten ayrıldıklarında katlanacakları maliyetleri ya da örgütte kalmaları durumunda sağlayacakları faydayı dikkate alarak bağlanmalarını ifade eder. Örgüt literatüründe Meyer ve Allen'in iki şekilde açıkladıkları bağlıık türüne daha sonraları "normatif bağlıık veya ahlaki bağlıık" ifadesi de kazandırılmıştır. Normatif bağlıık, bireylerin örgüte hesapsız bağ|lığı, örgüttün içinde bulunduğu her şart ve durumda örgütte kalmaları gerektiğini belirten katı ve zorunlu bir bağlılık türüdür (Özutku, 2008: 80). Örgütlerde yetenekli çalışanların örgüte bağ|ı̆̆ını sağlamak sadece çalışanlarla ilgili bir husus değildir. Örgütün önceliği uygun işlere en uygun kişileri atamalı ve onları yaptıkları işle içselleştirmelidir. Bu sayede örgüt hem bireyleri elde tutabilir hem de örgüte bağlılığı artırabilir. 


\subsubsection{Cezbetme}

Günümüzde işletmeler rekabet üstünlüğü elde etmek için birçok faktörün yanı sıra yetenekli insanlara da intiyaçları vardır. İşletmelerin insana bakış açılarının değişimiyle birlikte bir işletmenin var olması ya da yok olmasının yeteneğe bağlı olduğu farkındalığı oluşmaya başlamıştır (Faisal, 2008:14). Yüksek performanslı işletmeler için yeteneği cezbetmek ve elde tutmak temel hedefler arasında yer alır. Günümüzde yeteneği bulmak dahi beceri haline gelmiştir. Demografik, sosyal ve ekonomik ilerlemeler, sürdürülebilir rekabet ve karlıık artışlarının insan yeteneğiyle doğrudan ilgili olduğunu göstermiştir (Hiltrop, 1999: 428). Illerleyen yıllarda işveren ve işçi kavramları algısı çarpıcı bir biçimde değişecek ve önümüzdeki on yıllarda işletmeler çalışanları aramaya başlayacaklardır. Yetenekli çalışanları cezbetmek uygun insana uygun iletiyi vermekle mümkün olabilir. İşletmeler bu süreçte belirlenen yetenek kitlesini doğru tanımlamalı ve yetenekten beklentilerini açıkça ortaya koymalıdır.

Yeteneklerin işletme tarafından cezbedilmesi için uygun işe uygun yeteneği yerleştirmek gerekir. Yetenekleri çekmek için işletmelerin kullandıkları bazı kanallar bulunmaktadır. Hatum (2010) ile Li ve Devos (2008) cezbetmeye ilişkin birtakım önerilerde bulunmuşlardır;

- Yetenekli bireylere müşteri gözüyle bakmak

- İ̧sletmede bir yetenek yönetim sisteminin varlığı

- Takdir ve ödüllendirmede, şirket ortaklığı ve hissedar olmada, performansa dayalı ücretlendirmede yetenekli çalışanlara güvence vermek

- İ̧̧ esnekliği ve pozitif bir örgüt iklimine sahip olmak

- Eğitimlerin bireye uygun olması ve bireyin gelişimine katkı sağlaması gerekir

- Liderlik yönetim uygulamalarının vizyoner olması

- Performans ölçümü ve yedekleme planlarının sürekli olarak yapılmasıdır (Chowdhury, 2001:12).

\subsubsection{Yetenek Havuzu}

Yetenek Yönetimi tipik olarak yetenekli ve performans açısından en üst düzeyde olan çalışanları belirli bir havuz içinde tutar. Bu çalışanlar gelecekte belirli noktaların potansiyel liderleri olarak kabul edilirler. Dışarıdan yetenek kiralamak Yetenek Yönetiminin önemli bir parçası olmasına rağmen örgütlerin temel işlevleri mevcut çalışanlarından havuzlar oluşturmaktır (Stahl vd. 2021: 2532). Yetenek havuzları, örgüt içindeki ayrı düzeylerdeki yüksek potansiyelli bireyleri ayrı havuzlarda birleştirir. Bu sayede istenilen pozisyonlardaki bireyler yedeklenmiş olur ve ihtiyaç durumunda pozisyona uygun kişilerin bu havuzlardan belirlenmesi daha hızlı ve maliyeti düşük olur. Yetenek havuzu yaklaşımındaki temel hedef yüksek potansiyelli bireylerin birikimlerinin geliştirilmesi ve örgüt içi etkililiğin ve verimliliğin artııımasıdır. Bunun yanı sıra yetenek havuzları aldıkları eğitimler, 
mevcut potansiyelleri ve istenilen seviyedeki çalışmalarıyla gelecekte oluşabilecek büyümenin yapı taşlarını meydana getirirler (Berger, 2004: 187-188).

Örgütler, yetenek havuzuna seçtikleri bireylere mecburi eğitim vermektedirler. Bu eğitimler ile adaylara, yöneticilik potansiyellerinin belirlenmesi amacıyla psikoanalitik analizler, mülakatlar, potansiyelin saptanmasına dönük değerlendirme merkezi uygulamaları ve çalışanların yüksek iş performansına sahip olmasına yönelik özellikler aranır. Bu özellikler içinde; bireyin başarma arzusu, sağduyu sahibi olma ve sözlü iletişim becerisinin yüksekliği gibi yetkinlikler bulunmakta ve bireyden öğrenme isteğinin sürekli olması istenmektedir (Altınöz, 2006: 101-102).

\subsubsection{Seçme-Yerleştirme}

Yetenekli bireylerin istihdam edilmeleri ve işe alınma süreçleri geleneksel işe alım süreçlerinden çok farklıdır. Sayıca fazla namzet listesinden birini belirlemek yeteneği seçmek anlamına gelmez. Örgütleri yeteneği bulmak için yenilikçi, yaratıcı ve aktif yöntemler kullanmaları gerekir. Örgütler daha aktif işe alım yöntemleri uygulayarak kendisinin bile yeteneğini fark etmediği bireylere ulaşabilirler. Yetenek bulma ve kadrolama süreçlerinin iki temel evresi, aday araştırma ve bulma sürecidir. Yetenek yönetimi, hem örgüt içi hem de örgüt dışı kaynaklardan yetenekli kişilere ulaşılabilmektir (Kraus, 2007: 66-67).

Yetenek yönetimine göre örgütsel strateji ve hedefler doğrultusunda belirlenmiş kilit pozisyonlar ancak pozisyona uygun yetenekli kişilerce doldurulur. Aranılan bütün özellikleri taşıyan adayları bulmak oldukça zordur. Bu beceri boşluğu sadece özel sektör için değil kamu sektörü için de geçerlidir. Günümüzde kamuda da yetenekli kişiler için savaş yapılmaktadır (Geniş ve Usta, 2010). Günümüz rekabet koşulları ve yetenekli kişi sayısının azlığı göz önünde bulundurulduğunda yetenekli insanlara sahip olmak örgütler için stratejik olarak ele alınması gerekli bir konu haline gelmiştir. Bu stratejik yaklaşım ile yetenek yönetimine en önemli girdi sağlayan süreç seçme ve yerleştirmedir (Kraus, 2007: 66-67).

Seçme ve yerleştirme araçlarının doğru kullanılması potansiyeli yüksek, yaratııı, yeniliklere açık, gelecek vadeden yeteneklerin örgüte çekilmesi ve doğru pozisyonda görevlendirmesi sürecin başarıya ulaşmasında önemli koşullardan biridir. Yetenek yönetiminde yöneticileri işe alım sırasında değerlendirme merkezi uygulamalarına yönelten sebepler; iş ortamlarına mesafe olarak yakın adayları net bir şekilde gözlemleyebilmek, her yönüyle adayları kıyaslayabilmek, objektif değerlendirmenin daha sağıklı olması gibi daha birçok nedenlerdir. Değerlendirme merkezi uygulamaları örgütlerin kilit pozisyonlarını seçme ve değerlendirmede, yetkinlikleri gözlemleme ve yeteneklerin ortaya çıkarılmasında etkindir. Bu yöntem aracılığıyla yüksek potansiyelli çalışanların belirlenmesi amaçlanmaktadır (Altınöz, 2006: 100). Bu amaçla değerlendirme merkezleri her işletme ve iş tanımında kendisine özgü özellikler taşıdığından dolayı standart uygulamalarla sınırlandırılamazlar. Fakat her işletme için geçerli ortak standartlar da mevcuttur. Gelişmiş ve gelişmekte olan örgütlerdeki yetenek yönetimi uygulamaları ele alındığında değerlendirme merkezinin sıklıkla başvurulan bir seçim ve değerlendirme yöntemi olduğu sonucuna varılır (Yazıcıoğlu, 2006:71-76). Nesnelliği, 
çoklu verilere dayanması, geri bildirimler de detay ve doğru pozisyonlara doğru kişilerin atanması gibi nedenler bu yöntemi işletmeler için gerekli kılmaktadır.

\section{Araştırmanın Amacı ve Önemi}

Rekabetin hızla yoğunlaştığı günümüz iş dünyasında işletmelerin dâhil oldukları sektörde avantajlı konuma gelmeleri için sistemlerini her zaman açık tutmalı ve pazardaki yenilikleri ve değişimleri takip etmeleri gerekmektedir. Bu gelişmeleri takip edebilmek için "yetenek" arayışlarına önem vermeli ve bu yetenekleri gerektiği ölçüde yönetebilmelidirler. Tüm bunlar yapıldığı takdirde rakiplerinden farklı değerlere sahip olabilirler ve daha avantajlı konuma gelebilirler. Yeteneklerin güncel tutulması ve geliştirilmesi, teknolojik, ulusal ve uluslararası değişimlerin belli zaman aralıklarında takip edilmesi yenileşmeyi daha aktif hale getirecektir. Buradan da anlaşılacağı üzere yeniliği artırabilecek bir faktör olan yeteneğin ve yeteneği yönetebilmenin işletmelerce kavranması ve uygulamaya sokulması gerekmektedir. Bu noktada işletmenin tamamına etkin görevler düşerken, sorumluluğun daha çok üst yönetim ve İnsan Kaynakları Yöneticilerine ait olduğu söylenebilir. Yapılan bu açıklamalar bağlamında araştırmanın amacı; Yetenek Yönetimi konusunda daha kapsayıcı bir ölçek geliştirmektir.

Araştırmanın konusu Türkiye'de faaliyet gösteren şirketlerin yetenek yönetimi uygulamaları oluşturmaktadır. Yapılan çalışma, Türkiye'de Güneydoğu Anadolu Bölgesi'nin gelişimi, ülkemiz ekonomisine kayda değer katkılar sağlayan tekstilin geleceği açısından oldukça önemlidir. Örgütlerin yeteneği yönetme eğilimleri, yetenekleri geliştirmeleri hayatta kalabilmelerinin temel şartıdır.

\subsection{Araştırmanın Kapsamı ve Verilerin Toplanması}

Araştırmada şirket seçiminde; çalışan sayısı, İKY uygulamalarındaki faaliyetleri ve işletmelerin yetenek yönetimi hakkında bilgi sahibi olup olmadıklarıyla ilişkin bir değerlendirme yapılarak çalışma yürütülmüştür. Anket çalışması Şanlıurfa Organize Sanayi Bölgesinde (ŞOSB) tekstil sektöründe faaliyet gösteren dört işletmede Mayıs-Haziran 2017 tarihleri arasında yapılmıştır. İşletmelerden, üst yönetim, orta yönetim, bölüm sorumluları ve işçilerden oluşan 1182 çalışandan gönüllük esasına göre veri sağlanmıştır. Anketler çalışanlara uygun zamanlarda dağıtılmış ve çalışanlarla birebir görüşülmüştür.

Türkiye'de işletmeler, çalışanların intiyaçlarına cevap verebilmek, yetenekli ve değerli çalışanları çekebilmek, onları işletmeye içerisinde geliştirmek ve işletmeye kazandırabilmek için yetenek temeline dayanan çeşitli yönetim şekilleri uygulamaktadırlar. İşletmenin iç ve dış çevresinde yaşanan hızı değişimler, teknolojik yenilikler, rekabet edilebilirliğin giderek zorlaştığı günümüz şartlarında İnsan Kaynakları Yönetiminin önemle üzerinde durması gereken hususlardan biri de yetenekli çalışanlara ulaşabilmektir. Araştırmaya katılan işletmelerin gerçek ad ve sloganları bu çalışmanın bilimsel araştırma amaçlı yapıldığından dolayı gizli tutulmuş ve simgelerle ifade edilmiştir. İşletmeler araştırmada A, B, C ve D işletmesi olarak isimlendirilmiştir. 


\section{Cengiz DURAN | Dursun BOZ | Sema BEHDiOĞLU | Songül KUTLU}

\subsection{Yöntem}

Yetenek Yönetimi Uygulamaları ile ilgili; Mucha (2004), Socpo (2005), Morton (2005), Fegley (2006), Mccauley ve Wakefield (2006), Lewis ve Heckman (2006), Bersin (2006), Doğan ve Demiral (2008), Laff (2006), Stewart (2008), Capelli (2008), Ooi (2009), Galagan (2009), Jimenez ve Martinez (2009), Çırpan ve Şen (2009), Altuntuğ (2009), Atı (2010), Silzer ve Dowel (2010), Alayoglu (2010), Şahin (2015), Demirel ve Savaş (2017), Altınöz (2018) çalışmaları incelenerek Yetenek Yönetimi Uygulamaları ile ilgili 64 ifade 4 kişilik çalışma ekibince taslak ölçek oluşturulmuştur. Uzmanlık alanları sırasıyla Kalite Yönetimi, İnsan Kaynakları, İstatistik ve Örgütsel Davranış olan çalışma grubu; 64 ifadeyi tek tek ele almak suretiyle oluşturmuştur. Likert tipinde (1.Hiç Katılmıyorum,- 5.Tamamen Katııyorum) ve 8 adet demografik bilgilerden oluşturulan anket 1182 çalışana uygulanmıştır. Araştırma verilerinin analizi için SPSS (18.0) ve AMOS (16.0) programı kullanılmıştır. Ölçekteki değişkenlerin tespitinde; güvenilirlik için Cronbach's Alpha Analizi, maddelerin faktör analizine uygunluğu testi için KMO and Bartlett's Testi, Betimleyici ve tanımlayıcı analizler, Açıklayıcı (Keşfedici) Faktör Analizi (AFA) ile Doğrulayıcı Faktör Analizi (DFA) yapıımıştır. Tüm analizler için anlamlılık seviyesi \%5 $(p=0,05)$ alınmış ve istatistiksel anlamlılık için $p<0,05$ düzeyi aranmıştır. Yetenek Yönetimi Uygulamaları ölçeğinin özdeğeri 1'den büyük 7 faktörde toplandığı belirlenmiştir.

\section{Bulgular}

Illk pilot uygulama 4 ( $A, B, C$ ve D) işletmedeki 200 çalışan ile yapılmıştır. Teorik olarak faktörleşmeyen ve faktör yükleri düşük ifadeler $(9,10,14,17,19,27,29,55,58$ ve 59) çıkarılarak 54 ifade ile 500 çalışana uygulanmıştır. İkinci pilot çalışmada teorik olarak faktörleşmeyen ve faktör yükleri düşük ifadeler (1, 11, 18, 28 ve 57) çıkartılmıştır. Nihai ölçek elde edilen 49 ifade ile 1182 çalışana gönüllülük esasına göre uygulanmıştır. Değişkenlere ilişkin güvenilirlik testi (Cronbach's Alpha) tüm ölçek için ,958 olarak (Tablo 1) çok güvenilir (Büyüköztürk, 2007) olduğu tespit edilmiştir.

Tablo 1. Güvenilirlik Analizi

\begin{tabular}{cc}
\hline \hline Cronbach'sAlpha Katsayısı & ifadeSayısı \\
\hline 958 & 49 \\
\hline
\end{tabular}


Eskişehir Osmangazi Üniversitesi Sosyal Bilimler Dergisi

Tablo 2. KMO and Bartlett's Test

\begin{tabular}{llr}
\hline \hline \multicolumn{2}{c}{ Kaiser-Meyer-Olkin MeasureofSamplingAdequacy. } &, 939 \\
\hline Bartlett's Test of Sphericity & Approx.Chi-Square & 44928,477 \\
& Df. & 1176 \\
& Sig. &, 000 \\
\hline
\end{tabular}

Faktör analizin yapılabilmesinde örneklem yeterliliğinin analizi için Kaiser-Meyer-Olkin (KMO) testi yapılmıştır. KMO katsayısı 0,9 üzeri mükemmel; 0,8-0,9 arası çok iyi; 0,7-0,8 arası iyi; 0,6-0,7 arası orta; 0,5-0,6 arası zayıf ve 0,5'in altı kabul edilemez (Kalaycı, 2010: 322). Tablo: 2'de KMO testinin 0,939 sonucuyla mükemmel olduğu tespit edilmiştir.

Tablo 3. Demografik Özellikler

\begin{tabular}{|c|c|c|c|c|}
\hline Demografik & Frekans & $\%$ & Geçerli \% & Kümülatif \% \\
\hline \multicolumn{5}{|c|}{ Katılımcı Cinsiyetleri } \\
\hline Kadın & 203 & 17.2 & 17.2 & 17.2 \\
\hline Erkek & 979 & 82.8 & 100 & 100 \\
\hline Toplam & 1182 & 100 & 100 & \\
\hline \multicolumn{5}{|l|}{ Yaş Bilgileri } \\
\hline $16-20$ & 45 & 3.8 & 3.8 & 3.8 \\
\hline $21-30$ & 871 & 73.7 & 73.7 & 77.5 \\
\hline $31-40$ & 252 & 21.3 & 21.3 & 98.8 \\
\hline $41-50$ & 14 & 1.2 & 1.2 & 100 \\
\hline Toplam & 1182 & 100 & 100 & \\
\hline \multicolumn{5}{|l|}{ Medeni Durum } \\
\hline Evli & 753 & 63.7 & 63.7 & 63.7 \\
\hline Bekar & 429 & 36.3 & 36.3 & 100 \\
\hline Toplam & 1182 & 100 & 100 & \\
\hline \multicolumn{5}{|c|}{ Öğrenim Durumları } \\
\hline Illkokul & 110 & 9.3 & 9.3 & 9.3 \\
\hline Ortaokul & 442 & 37.4 & 37.4 & 46.7 \\
\hline Lise & 527 & 44.6 & 44.6 & 91.3 \\
\hline Yüksekokul & 60 & 5.1 & 5.1 & 96.4 \\
\hline Lisans & 43 & 3.6 & 3.6 & 100.0 \\
\hline Toplam & 1182 & 100 & 100 & \\
\hline \multicolumn{5}{|l|}{ Çalıșma Süresi } \\
\hline $1-3$ yıl & 1066 & 90.2 & 90.2 & 90.2 \\
\hline
\end{tabular}




$\begin{array}{ccccc}\text { 4-6 yıl } & 103 & 8.7 & 8.7 & 98.9 \\ 7-9 \text { yıl } & 6 & 0.5 & 0.5 & 99.4 \\ \text { 10 yıl ve üstü } & 7 & 0.6 & 0.6 & 100 \\ \text { Toplam } & 1182 & 100 & 100 & \\ \begin{array}{c}\text { Katılımcı Unvanları } \\ \text { İşçi }\end{array} & 753 & 63.7 & 63.7 & 63.7 \\ \text { Sorumlu } & 345 & 29.2 & 29.2 & 92.9 \\ \text { Uzman Y. } & 42 & 3.6 & 3.6 & 96.4 \\ \text { Uzman } & 29 & 2.5 & 2.5 & 98.9 \\ \text { Yönetici } & 13 & 1.1 & 1.1 & 100.0 \\ \text { Toplam } & 1182 & 100.0 & 100.0 & \\ \text { İşletmeler } & & & & 21.2 \\ \text { İşletme A } & 250 & 21.2 & 21.2 & 41.7 \\ \text { İşletme B } & 243 & 20.6 & 20.6 & 64.3 \\ \text { Iş̧letme C } & 267 & 22.6 & 22.6 & 100 \\ \text { İşletme D } & 422 & 35.7 & 35.7 & \\ \text { Toplam } & 1182 & 100 & 100 & \end{array}$

Tabloya göre; Şanlıurfa Organize Sanayi Bölgesi'nde (ŞOSB) araştırmaya katılan çalışanların \%17.2'sinin kadın, \%82.8'inin ise erkek olduğu görülmektedir. Araştırmaya katılanların \%3.8'inin 16-20 yaş aralığında, \%73.7'sinin 21-30 yaş aralığında, \%21.3'ünün 31-40 yaş aralığında ve \%1.2'sinin 41-50 yaş aralığında olduğu görülmektedir. Araştırmaya katılanların \%63.7'sinin evli, \%36.3'ünün ise bekar olduğu görülmektedir. Araştırmaya katılanların \%9.3'ünün İlkokul mezunu, \%37.4'ünün İlköğretim mezunu, \%44.6'sının Lise mezunu, \%5.1'inin Yüksekokul mezunu ve \%3.6'sının Lisans mezunu olduğu görülmektedir. Araştırmaya katılanların çalışma süreleri \%90.2'sinin 1-3 yıl arası çalıştığı, \%8.7'sinin 4-6 yıl arası çalıştığı, \%0.5'inin 7-9 yıl arası çalıştığı, $\% 0.6$ 'sının ise 10 yıl ve üzeri çalıştıkları görülmektedir. Araştırmaya katılanların unvanlarına göz atılırsa; \%63.7'sinin işçi oldukları, \%29.2'sinin Sorumlu oldukları, \%3.6'sının Uzman yardımcısı oldukları, \%2.5'inin Uzman oldukları, \%1.1'i ise Yönetici olduklarını beyan etmişlerdir. Nihai uygulamada elde edilen 7 faktörlü ölçeğin doğrulanıp doğrulanmayacağını testi için yapılan Yamaç Eğim Grafiği incelendiğinde 7 faktörlü yapı Şekil: 2 ile doğrulandığı görülmüştür. 
Şekil 2. Yamaç Eğim Grafiği

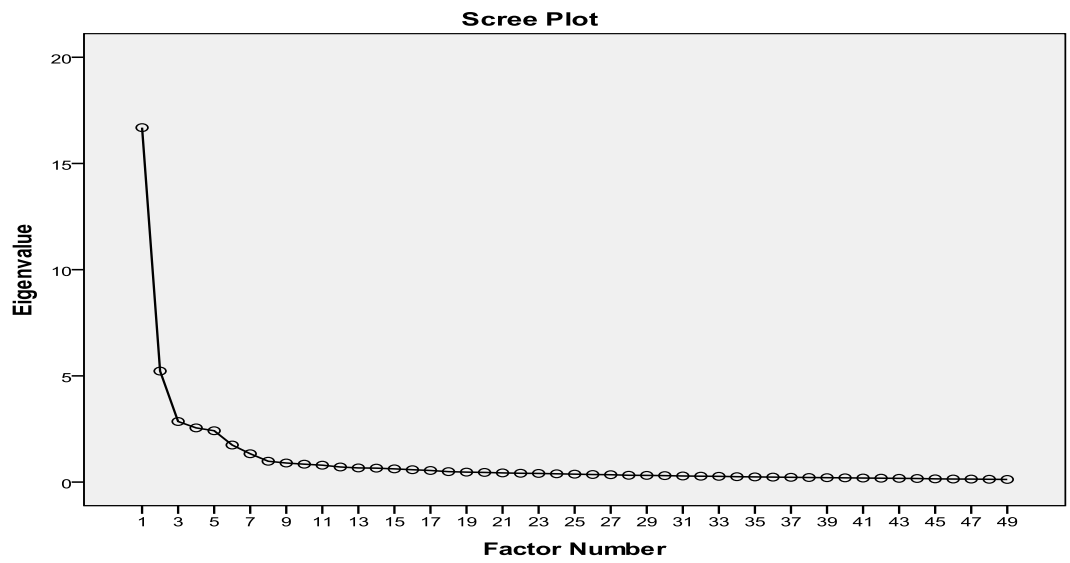

1182 örneklemle elde edilen 7 faktörlü ölçeğin doğrulanıp doğrulanmayacağının kontrolü için Açıklayıcı (Keşfedici) Faktör Analizi (AFA) yapılmıştır. Bu analizde Eğik Döndürme (Promax) Yöntemi, Çıkarım yöntemi (Extraction) Maksimum Benzerlikler (Maximum Likelihood) kullanılarak faktör yükleri ,40'dan (Absolute Value Below) büyük ve özdeğeri (Eigenvalue) 1'in üzerindeki faktörler kullanılmıştır.

Tablo 4. Açıklayııı Faktör Analizi (AFA)

\begin{tabular}{|c|c|c|c|c|c|c|c|c|}
\hline \multirow[b]{2}{*}{ Faktörler } & \multirow{2}{*}{ ifadeler } & \multicolumn{7}{|c|}{ Faktörler } \\
\hline & & 1 & 2 & 3 & 4 & 5 & 6 & 7 \\
\hline \multirow{11}{*}{ 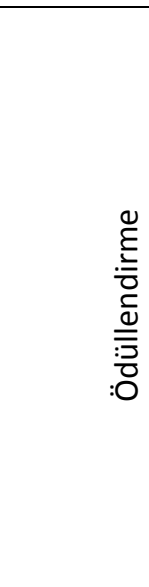 } & 36 & ,856 & & & & & & \\
\hline & 38 & ,852 & & & & & & \\
\hline & 41 & ,844 & & & & & & \\
\hline & 37 & ,827 & & & & & & \\
\hline & 40 & ,826 & & & & & & \\
\hline & 35 & ,805 & & & & & & \\
\hline & 39 & ,804 & & & & & & \\
\hline & 43 & 743 & & & & & & \\
\hline & 44 & ,737 & & & & & & \\
\hline & 42 & 682 & & & & & & \\
\hline & 34 & 654 & & & & & & \\
\hline
\end{tabular}




\section{Cengiz DURAN | Dursun BOZ | Sema BEHDiOĞLU | Songül KUTLU}

\begin{tabular}{|c|c|c|c|c|c|c|c|}
\hline & \multirow{8}{*}{ 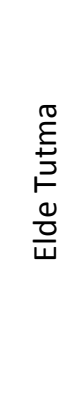 } & 25 & 940 & & & & \\
\hline & & 26 & ,874 & & & & \\
\hline & & 23 & ,862 & & & & \\
\hline & & 24 & ,859 & & & & \\
\hline & & 22 & ,827 & & & & \\
\hline & & 20 & ,667 & & & & \\
\hline & & 21 & ,642 & & & & \\
\hline & & 19 & ,627 & & & & \\
\hline & \multirow{7}{*}{ 占 } & 28 & & ,885 & & & \\
\hline & & 32 & & ,848 & & & \\
\hline & & 29 & & ,840 & & & \\
\hline & & 31 & & ,817 & & & \\
\hline & & 33 & & 739 & & & \\
\hline & & 30 & & ,711 & & & \\
\hline & & 27 & & 681 & & & \\
\hline \multirow{7}{*}{ 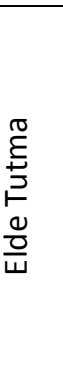 } & \multirow{7}{*}{ 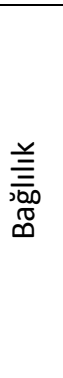 } & 14 & & & ,858 & & \\
\hline & & 15 & & & ,839 & & \\
\hline & & 16 & & & ,808 & & \\
\hline & & 17 & & & 691 & & \\
\hline & & 18 & & & 615 & & \\
\hline & & 13 & & & 606 & & \\
\hline & & 12 & & & ,465 & & \\
\hline & \multirow{7}{*}{ 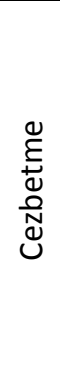 } & 05 & & & & ,894 & \\
\hline & & 06 & & & & ,851 & \\
\hline & & 07 & & & & ,786 & \\
\hline & & 03 & & & & ,621 & \\
\hline & & 04 & & & & ,577 & \\
\hline & & 02 & & & & ,447 & \\
\hline & & 01 & & & & ,411 & \\
\hline \multirow{2}{*}{ 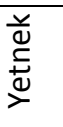 } & \multirow{2}{*}{$\begin{array}{l}\sum_{N}^{N} \\
\stackrel{N}{N} \\
\text { I } \\
\end{array}$} & 48 & & & & & ,932 \\
\hline & & 49 & & & & & 877 \\
\hline
\end{tabular}




\begin{tabular}{|c|c|c|c|c|c|c|c|c|c|}
\hline \multicolumn{3}{|c|}{47} & & & & & \multicolumn{3}{|c|}{,836 } \\
\hline & & 46 & & & & & \multicolumn{3}{|c|}{ 738 } \\
\hline & & 45 & & & & & & ,566 & \\
\hline \multirow{4}{*}{ 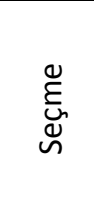 } & \multirow{4}{*}{ 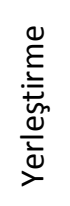 } & 10 & & & & & & & ,926 \\
\hline & & 11 & & & & & & & ,818 \\
\hline & & 08 & & & & & & & ,438 \\
\hline & & 09 & & & & & & & ,414 \\
\hline \multicolumn{3}{|c|}{ Cronbach's Alpha } & 947 & 946 & 917 & 907 & ,876 & 911 & ,832 \\
\hline
\end{tabular}

Tabloda görüldüğü gibi faktör yükleri 0.411 ile 0.940 arasında değişmektedir. Güvenilirlik katsayısı Cronbach's Alpha Değeri 0.958 ile çok iyidir. 7 faktörlü ve 49 ifadeden oluşan ölçeğin KMO. değeri 0.939 ile çok iyi olduğu ve toplam varyansın \%61.730'unu açıkladığı belirlenmiştir. Bu sonuçla ölçeğin yeterli güvenilirlik seviyesine sahip olduğu görülmektedir.

Doğrulayııı Faktör Analizi (DFA) için AMOS 16 paket programı kullanılarak Yapısal Eşitlik Modeliyle 1182 çalışan ile test edilerek Şekil: 3'deki grafikte sunulmuştur. AMOS grafiği şekilde; "ÖD: Ödüllendirme”, "ET: Elde Tutma”, "EG:Eğitim”, “ETB: Elde Tutma ve Bağ|lık”, “CZ: Cezbetme”, "YH: Yetenek Havuzu" ve "SY: Seçme Yerleştirme" olarak kodlanmıştır. Ölçeğe ait iyi uyum indeksi sonuçları Tablo: 6’da görülmektedir. 
Cengiz DURAN | Dursun BOZ | Sema BEHDiOĞLU | Songül KUTLU

Şekil 3. Doğrulayıcı Faktör Analizi (DFA)

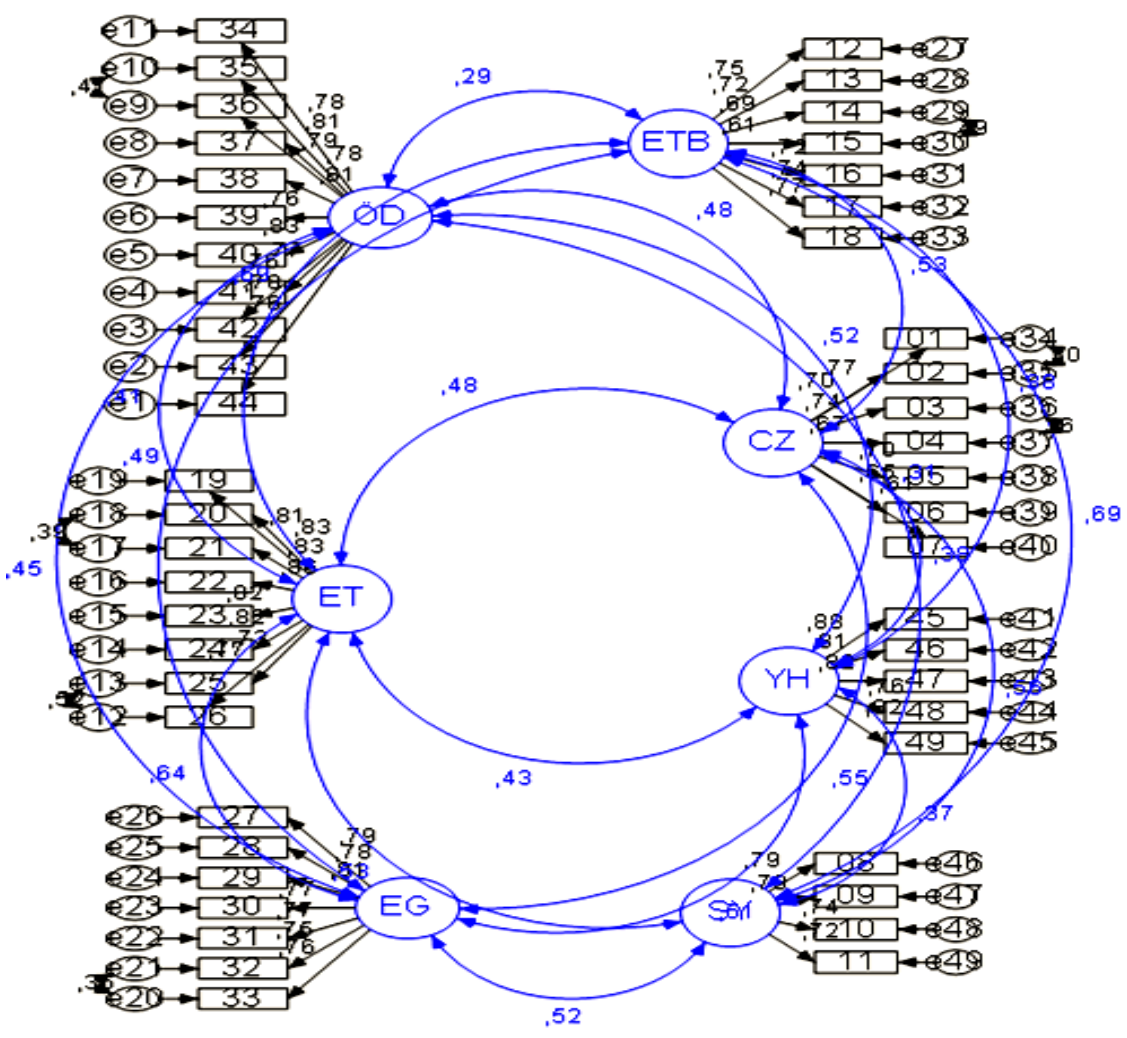


Tablo 5. YEM Uyum İndeks Değerleri

\begin{tabular}{ccc}
\hline \hline Uyum Ölçüsü & iyi Uyum & Kabul Edilebilir Uyum \\
\hline $\mathrm{X}^{2}$ & $0 \leq \mathrm{X}^{2} / \mathrm{sd} \leq 3$ & $3 \leq \mathrm{X}^{2} / \mathrm{sd} \leq 5$ \\
$\mathrm{GFI}$ & $0,90 \leq \mathrm{GFI} \leq 1,00$ & $0,85 \leq \mathrm{GFI} \leq 0,90$ \\
$\mathrm{RMR}$ & $0,00 \leq \mathrm{RMR} \leq 0,05$ & $0,06 \leq \mathrm{RMR} \leq 0,08$ \\
$\mathrm{NFI}$ & $0,95 \leq \mathrm{NFI} \leq 1,00$ & $0,90 \leq \mathrm{NFI} \leq 0,95$ \\
\hline
\end{tabular}

Kaynak: Meydan ve Şeşen, 2015:37; Schermelleh-Engel vd. 2003

Tablo 6. Ölçeğin Doğrulayıcı Faktör Analizi Uyum Indeksi Sonuçları

\begin{tabular}{lllclll}
\hline \hline$X^{2}$ & $f$ & $p$ & $X^{2} / d f$ & GFI & $R M R$ & NFI \\
\hline \multirow{2}{2}{2956,496} & 1099 & ,000 & 2,69 & ,985 & ,041 & \multirow{2}{*}{983} \\
\hline
\end{tabular}

Tablo 6'da görüldüğü gibi $p$ değeri anlamlı çıkmıştır. Analiz sonucu $X^{2} / d f=2,69$ olarak tespit edilmiş ve anakütle varyans-kovaryans matrisi ile tahmin edilen varyans-kovaryans matrisinin uyumlu olduğu tespit edilmiştir. GFI değeri 0,985 ile iyi uyum referans değerleri içerisinde olduğu görülmektedir. RMR ve NFI değerleri sırasıyla 0,041 ve 0,983 olarak tespit edildiğinden iyi uyum değerleri göstermektedir. Hesaplanan uyum indeksi sonuçları dikkate alındığında ölçeğin istatistiksel olarak anlamlı bir model olduğunu söylenebilir (Meydan ve Şeşen, 2015:32-37, Çokluk vd. 2016:272-286).

Yetenek Yönetimi Uygulamaları ölçeği 5 noktalı Likert tipinde 49 ifadeden oluşmaktadır. Yetenek Yönetimi Uygulamaları Ölçeği 1182 örneklem üzerinden güvenilirlik ve geçerlilik analizi yapılmıştır. Açımlayıcı (AFA) ve Doğrulayııı Faktör Analizi (DFA) ile 7 faktörlü bir yapı ile toplam varyansın \%61,730'u açıklamaktadır. Faktörlerin isimleri; 1. Ödüllendirme, 2. Elde Tutma, 3. Eğitim, 4. Elde Tutma ve Bağılık, 5. Cezbetme, 6. Yetenek Havuzu ve 7. Seçme Yerleştirme olarak adlandırılması uygun görülmüştür. Faktörlerdeki ifade sayıları; 11, 8, 7, 7, 7, 5, 4'tür. Yapılan istatistiki analizlerin sonucunda faktör yük değerlerinin $(0,41-0,94)$ yüksek olması ölçeğin yapı geçerliliğine sahip olduğunu göstermektedir. Ölçeğe ait Cronbach Alpha değeri ,958 ve örneklem yeterlilik değeri ,939 sonuçlarıyla çok iyi olduğu görülmektedir. Yetenek Yönetimi Uygulamaları ölçeğinden alınabilecek en düşük puan 49 iken en yüksek puan 245'dir. 5 noktalı Likert tipi ölçeklerde hem ölçeğin hem de alt faktörlerinin ortalama değerleri; 
“Hiç Katılmıyorum "1.00-1.79" $\rightarrow$ Çok zayıf Yetenek Yönetimi Uygulamalarını,

“Katılmıyorum "1.80-2.59” $\rightarrow$ Zayıf düzeyde Yetenek Yönetimi Uygulamalarını,

“Kararsızım "2.60-3.39” $\rightarrow$ Orta düzeyde Yetenek Yönetimi Uygulamalarını,

“Katılıyorum "3.40-4.19” $\rightarrow$ Yüksek düzeyde Yetenek Yönetimi Uygulamalarını,

“Tamamen Katılıyorum "4.20-5.00” $\rightarrow$ Çok Yüksek düzeyde Yetenek Yönetimi Uygulamalarını ifade etmektedir.

\section{Sonuç}

Örgütsel yetenek ile ilgili tanımlamalardan varılacak en birincil sonuç bu yeteneklerin örgütler için rekabet avantajı sağlayacak olduklarıdır. Diğer bir ifade ile örgütsel anlamda yetenekleri gelişmiş olan örgütlerin, mevcut kapasitelerini rakiplerine göre daha etkin ve verimli kullanacakları ve bu sayede de müşteri ve pazar paylarını koruyacakları beklenmektedir. Bu araştırma ile Yetenek Yönetimi Uygulamaları konusunda alanyazındaki ölçeklerden daha kapsayıcı bir ölçek geliştirmek amaçlanmıştır. Bu amaçla Yetenek Yönetimi Uygulamaları Ölçeği Şanlıurfa Organize Sanayi Bölgesi'nde tekstil sektöründe faaliyette olan 4 ayrı işletmedeki 1182 çalışana uygulanmıştır. Bunun sonucunda söz konusu 4 işletmenin yüksek düzeyde Yetenek Yönetimi Uygulamaları yaptığı tespit edilmiştir. Değişik demografik özellikleri taşıyan çalışanlara uygulandığından dolayı geçerli, güvenilir bir ölçüm aracı olduğu değerlendirilmektedir.

Alanyazında ölçekler dikotomik yaklaşımla nitel çalışmalardan nicel çalışmalara doğru eklektik şekilde geliştirilmektedir. Bu bağlamda Yetenek Yönetimi Uygulamaları ölçeği de bu yaklaşımın bir ürünüdür. Alanyazında yapılmış olan birçok çalışmada nitel çalışma (vaka çalışması, mülakat vb.) kullanıımış fakat az sayıda nicel çalışmaya rastlanmıştır. Kılıç vd. (2017) tarafından Oehley (2007) çalışmasından Türkçe'ye uyarlanan yetenek yönetimi ölçeği 40 ifade ve 8 alt faktörden (Anlama, İşe alma, Belirleme, Geliştirme, Olumlu iliş̧kiler, Yetkilendirme, Ödüllendirme ve İş-Yaşam Dengesi) oluşan ( $n=133$ ) katılımcı öğretmen adayları üzerinden test edilerek geliştirilmiştir. Tabancalı vd. (2017) eğitim organizasyonlarında yetenek yönetimi ölçeği çalışmasında 50 ifade ve 6 alt faktörden (Amaç ve stratejilerin tanımlanması, Anahtar konumların belirlenmesi, Yetenekleri yetenek havuzuna çekme, Eğitim ve geliştirme, Performans değerlendirme, Kariyer gelişimi) oluşan ( $n=784)$ katıımcı müdür, müdür yardımcısı ve öğretmenler üzerinden test edilerek geliştirilmiştir. Jayaraman vd. (2018) Entegre Yetenek Yönetimi Ölçeği 26 ifade 4 alt faktörden (Kritik pozisyonların belirlenmesi, Yeterlilik eğitimi, Gelişme ve Ödül yönetimi) oluşan ( $n=506)$ çalışan üzerinden test edilerek geliştirilmiştir. Erdoğan (2019) yetenek yönetimi ölçeği geliştirilmesi çalışmasında 24 ifade ve 4 alt faktörden (Ĕgitim ve gelişim, Kariyer yönetimi, Çalışan seçimi ve işe alım, Performans yönetimi) oluşan ( $n=751$ ) katıımcı telekomünikasyon çalışanları üzerinden test edilerek geliştirilmiştir. Yetenek Yönetimi Uygulamaları Ölçeği çalışmamızda 49 ifade ve 7 alt faktörden (Ödüllendirme, Elde Tutma, Eğitim, Elde Tutma ve Bağlılık, Cezbetme, Yetenek Havuzu ve Seçme Yerleştirme) oluşan $(n=1182)$ işletme çalışanı üzerinden test edilerek geliştirilmiştir. Bu bağlamda çalışmanın üstünlük- 
leri örneklem ve alt faktörler açısından daha kapsayıcı olduğu, ölçekle ilgili elde edilen istatistiksel değerlerin (güvenilirlik, örneklem yeterliliği, açımlayıcı faktör analizi, doğrulayıcı faktör analizi, yamaç eğim grafiği, açıklanan varyans vb.) iyi/çok iyi ve uyum değerlerinde olduğudur. Çalışmanın sınırlııkları ve zayıflı̆̆ı ise çalışanların ifadeleri uzun bulması, mola ve yemek vakitlerinde zaman ayırmaları ile sadece Şanlıurfa Organize Bölgesindeki işletme çalışanlarınca yapılmasıdır. Bu ölçek farklı şehir, sektör ve örneklem grupları ile geçerlilik ve güvenilirlik analizleri Yetenek Yönetimi Uygulamaları Ölçeği ile çalışacak araştırmacılara açıktır. Bu açıklık tekrar test yöntemiyle ölçeğin güvenilirliğine katkı sağlayacaktır. Bu ölçeği kullanacak araştırmacıların örgütsel davranış konuları (Örgütsel Güven, Örgütsel Adalet, Örgütsel Bağ|lık, Personel Güçlendirme, Duygusal Emek, Örgütsel Vatandaşlık Davranışı vb.) ve örgütsel çıktılar (İş Performansı, İşletme Performansı, Verimlilik vb.) ile ilgili çalışmalar yapması önerilebilir.

İşletme hedeflerine ulaşması, farklı unsurların belirlediği bir başarı göstergesidir fakat bir bütünü temsil eder. Buradan hareketle bir işletmenin dönemsel veya bütünleşik performansı söz konusu olduğunda, bu performansın meydana gelmesine etki eden nedenlerin tamamının eş zamanlı olacak şekilde açıklandığının bilinmesi gereklidir. Soyut bir kavram olarak algılansa da bundan daha fazla olarak finansal ve beşeri varlıklardan meydana gelen ve bu varlıklarda ortaya çıkan bir bütünün nihai göstergelerini ifade eder. Bu beşeri varlıkların anlaşılması amacıyla araştırma sonuçlarının Türkiye'de özellikle gelişmekte olan ve yeni faaliyete geçmiş işletmelerin gelişimlerine katkı sağlayacağı değerlendirilmektedir. Dünyanın en akıllı varlığını, yani insanı ve insanın yeteneklerini tanımayla alakalı psikometrik özellikleri içeren bu çalışma alanyazındaki önemli boşluğu dolduracağı düşünülmektedir.

\section{Kaynaklar}

Akar, F. (2012). Yetenek Yönetiminin Bazı Türk Üniversitelerinde Uygulanmasına Illişkin Öğretim Üyelerinin Görüş ve Önerileri, Yayınlanmamış Doktora Tezi, Ankara Üniversitesi, EBE., Ankara.

Alayoğlu, N. (2010). İnsan Kaynakları Yönetiminde Yeni Dönem: Yetenek Yönetimi, Ticaret ve Turizm Eğitim Fakültesi Dergisi, Sayı: 1, ss. 75.

Altınöz, M. (2018). Yetenek Yönetiminin Algılanması Üzerine Karşılaştırmalı Bir Araştırma. Selçuk Üniversitesi, SBE.Dergisi, (39), 82-95.

Altınöz, M. (2006). Yetenek Yönetiminin Algılaması Üzerine Karşılaştırmalı Bir Araştırma, Yüksek Lisans Tezi, Çukurova Üniversitesi, SBE., Adana.

Altıntaş, M. (2018). İnsan Kaynaklarında Yeni Bir Yaklaşım: Yetenek Yönetimine iliş̧in Nitel Bir Araştırma. Ahi Evran Üniversitesi IİBF. Dergisi, 2(1), 24-43.

Altuntuğ, N. (2009). Rekabet Üstünlüğünün Sürdürülmesinde Yeteneklerin Rolü, Süleyman Demirel Üniversitesi, i.i.B.F.Dergisi, Cilt.14, Sayı.3, ss.445-460.

Armstrong, M. (2006). A Handbook of Human Resource Management Practice, (10th edition). Philadelphia: USA, and London, UK: Kogan Page Ltd. ss.484. 
Ashton, C., Morton, L., (2005). Managing talent for competitive advantage: Taking a systematic approach of talent management. Strategic Human Resource Review, 4(5), ss. 28-31. https://doi.org/10.1108/14754390580000819 (Erișim: 2.09.2017)

Atlı, D., (2010). İnsan Kaynakları Yönetiminin Yeni Vizyonu Yetenek Yönetimi ve Basın İşletmelerinde Bir Uygulama, Doktora Tezi, Marmara Üniversitesi, SBE., İstanbul, ss. 235-236.

Atlı, D. (2012). Yetenek Yönetimi. Crea Yayıncılık, İstanbul.

Bayramoğlu, G. (2007). Kaynak Tabanlı Yönetim Modelinin Rekabetçi Üstünlükler Açısından İncelenmesi ve Ford Otosan, Tusas, Graham ve Toprak Seramik İşletmelerinde Niteliksel Bir Araştırma, Yayınlanmamış Doktora Tezi, Anadolu Üniversitesi, SBE., Eskişehir.

Berger, L. A. (2004). Creating a Talent Management System for Organisation Excellence: Connecting the Dots, The Talent Management Handbook, McGraw Hill: NY. ss. 187-188.

Bersin, J. (2006). Talent Management: What is it? Why now, May. Çevrimiçi: http://www.bf.umich.edu/docs/KeyReferenceArticles.pdf.

Bingöl, D. (1998). İnsan Kaynakları Yönetimi, Beta Basım Yayım Dağııım İstanbul.

Boone, L., Kurtz D. L. (1998). Contemporary Marketing, The Dryden Press, Texsas.

Buckingham, M., Vosburgh, R. M. (2001). The 21st Century Human Resources Function: It's The Talent, Stupid! HR. Human Resource Planning, Vol:24, No:4, ss.17-23.

Büyüköztürk, Ş. (2007). Sosyal Bilimler için Veri Analizi El Kitabı, 7. Baskı, Ankara: Pegem Akademi Yayıncilık.

Born, M., Heers, M. (2009). Talent Management. Born, M., \& Heers, M. (2009). Talent Management: Alternatives to the Single-Ladder Approach. Faculty Report, 1-108.

Boxall, P. (1996). The Strategic HRM Debate and The Resource Based View of The Firm, Human Resource Management Journal, 6, ss.59-75

Brewster, C. (1994). Leeway With Labour, Personnel Today, August, 1.

Byars, L., Byars, L.W.R. (1997). Human Resources Management, 5.Ed., Irwin Inc.Co.

Capelli, P. (2008). Talent Mangement fort he Twenty-First Century, Harvard Business Review, March, ss.74-81.

Chowdhury, M.S., Amin, M.N.A. (2001). Relative İmportance of Employee Values, Attitudes Leadership Behaviors in Employee Motivation. An Emprical İnvestigation. Monroe Collage, Bronx, New York West Virginia University of Technical, ss. 12. 
Çırpan, H., Şen, A. (2009). İşletmelerde Yenilikçiliği Geliştirmede Etkili Bir Araç: Yetenek Yönetimi, Çerçeve Dergisi, Cilt:17, Sayı:52, s.110-117.

Çokluk, Ö., Şekercioğlu, G., Büyüköztürk, Ş. (2014). Sosyal bilimler için çok değişkenli istatistik: SPSS ve LISREL uygulamaları. Pegem Akademi.

Demirel, Y., ve Savaş, Y. (2017). Nepotizmin yenilik ve yetenek yönetimi üzerine etkisi. MANAS Sosyal Araştırmalar Dergisi,6(1), 129-142.

Doğan Südaş, H. ve Demiral, Ö. (2008). İnsan Kaynakları Yönetiminde Çalışanların Kendilerine Doğru Yolculuk Yöntemi: Yetenek Yönetimi, Ç.Ü. SBE.Dergisi, 17(3), ss.145-166.

Erçokses, B. (2009). Training And Development of Employees In Talent Management Process and An Application, Yayınlanmamış Yüksek Lisans Tezi, Marmara Üniversitesi, SBE., İstanbul.

Erdoğan, M.E. (2019). Developing A Scale Of Talent Management: A Study On Telecommunication Professionals In Turkey 1. Iş, Güç: Endüstri Ilişkileri ve İnsan Kaynaklari Dergisi, 21(2), 47-74.

Ertürk, M. (2009). İşletme Biliminin Temel IIlkeleri, Beta Yayınları, İstanbul.

Eryiğit, N. (2012). Multinational Firms as Technology Determinants in The New Era Developing Countries: Survey in Turkey, VIII. International Strategic Management Conference, Barcelona, Spain, ss.1139-1145.

Faisal, A. (2008). How Do Big Europen Companies Present Tliemselves Ta Attract The Most Talented People, Unpublished Master Theis, Uni versity Of Kalmar, Baltic Business School.

Fegley, S. (2006). Talent Management: Survey Report. Society for Human Resource Management.

Ferris, G. R., Hochwarter, W., Ronald, A., Buckley, Gloria, H.C., Dwight, F.(1999). Human Resource Management: Some New Directions, Journal of Management, 25, ss. 385-415.

Fındıkçı, İ. (1999). İnsan Kaynakları Yönetimi, Alfa Basım Yayım Dağıım, İstanbul.

Galagan, P. (2009). The New Face of Talent Mangement, American Society for Training \& Develeopment (ASTD), Whitepaper, Publication Department, Alexandria VA, ss.1-18.

Geniş, N., Usta, M. (2010). Yetenek Yönetimi ve Yetenekli Personelin Bulunması ve İşe Alımı, http://www.metinusta.net/events/talent\%20management.pdf.

Gündüzalp, S., ve Özan, M. B. (2018). Yetenek savaşlarından yetenek yönetimine. Journal of Anatolian Education Research, (2), 14-46.

Hatum, A. (2010). Next generation talent management: Talent management to survive turmoil. Palgrave Macmillan.

Hedberg, L., Helenius, M. (2007). What Leaders Can Do To Keep Their Key Employees Retention Management.Göteborg,ss.179. h https://gupea.ub.gu.se/bitstream/2077/4733/1/07-26.pdf 29.09.2017 
Hewit Associates (2005). Bağ|ı Çalışanların İş Sonuçları Üzerine Etkisi: Çalışan Bağ|ılığı Araştırması.

Hiltrop, J.M. (1999). The Quest for the Best: Human Resource Practices to Attract and Retain Talent, European Management Journal, 17 (4), ss.422-430.

Inskeep, N.A., Hall, B. (2008). Reward and recognition concepts that support talent and knowledge management initiatives. In V. Vaiman and C.M. Vance (eds) Smart Talent Management - Building Knowledge Assets for Competitive Advantage. 161-175. Elgar Publishing, UK.

Jackson, S.,Randall, S., Rivero, C. (1989). Organizational Characteristics as Predictors of Personnel Practices, Personnel Psychology, 42(4), ss.727.

Jayaraman, S., Talib, P., \& Khan, A. F. (2018). Integrated Talent Management Scale: Construction and Initial Validation. SAGE Open, 8(3), 2158244018780965.

Jiménez-Jiménez, D., Martínez, C. M. (2009). The Performance Effect of HRM and TQM: A Study in Spanish Organizations, International Journal of Operations \& Production Management, 29 (12), ss.1266-1289.

Kalaycı, Ş. (2010). SPSS Uygulamalı Çok Değişkenli İstatistik Teknikleri, 5.Baskı., Asil Yayın Dağıım, Ankara.

Kasımov, R. (2006). İnsan Kaynakları Yönetiminde Eğitim ve Geliştirmenin Önemi: Azerbaycan'da Faaliyet Gösteren Büyük Ölçekli İşletmelerde Bir Uygulama, Yüksek Lisans Tezi, Niğde Üniversitesi, SBE., Niğde.

Kaye, B., Jordan-Evans, S. (2003). How to retain high-performance employees. The 2003 Annual, 2, ss. 291-298.

Kılıç, E.D., Serin, H., Karakuş, O., Ergene, O., Çorbaci, E.C., \& Kılıç, N. (2016). Adaption of Talent Management Scale into Turkish: Sinop University Case. Journal of Education and Training Studies, 5(1), 124-133.

Kraus, J. (2007). Succession Planning and Talent Managment Recomandation to Reduce Workforce Attrition and Prepare for An Aging Population, P.H.D. Thesis, Wilmington Universitey, ss. 66-67.

Laff, M. (2006). Talent Management From Hire To Retire, T+D, November, 60(11), pp.42-48.

Kumudha, S., Senthilkumar, S.A. (2012). Talent management: Importance, procsess, retention and strategies for business organization. Int. J. Commer Econ Manage, 2012, 2.6: 78-85.

Lewis, R., Heckman, R. (2006). Talent management: A critical review. Human Resource Management 
Review.16,ss.139.154.https://www.google.com.tr/search?q=•\%09Lewis,+R.+E.++(2006).+Tal ent+management:\&tbm 29.09.2017

Li, F., Devos, F.P. (2008). Talent Management: Art or Science: The Invisible Mechanism Between Talent and Talent Factory. Unpublished master?s thesis, University of Kalmar, Sweden.

Matsusaka, J. (2001). Corporate Diversification, Value Maximization, and Organizational Capabilities, Journal of Business, C:74, No:3, . ss.414.

Mccauley, C., Wakefield, M. (2006). Talent management in the 21st century: Help your company find, develop and keep its strongest workers. The Journal for Quality \&Participation, Vol.29, No.4, ss.4-7.

Meydan, C. H., Şeşen, H. (2011). Yapısal eşitlik modellemesi AMOS uygulamaları. Detay Yayınclık.

Meyer, J. P., Allen, N.J. (1991). A three-component conceptualization of organizational commitment. Human resource management review, 1(1), 61-89.

Morton, L. (2005). Talent Management Value Imperatives: Strategies for Successful Execution, Research Report R-1360-05-RR, Conference Board.

Mucha, R.T. (2004). The Art And Science of Talent Management, Organization Development Journal, Winter, 22 (4), ss.96-100.

Ooi, C. (2009). Surviving the war for talent in Asia: how innovation can help. IBM Press, Crawfordsville, Indiana, USA: R.R. Donnelley in Crawfordsville: Indiana, ss. 38-138-160.

Özdemir, Y. (2010). Türkiye'deki İnsan Kaynakları Yönetimi Anlayışının Belirlenmesine Yönelik Bir Araştırma: isO 500 Örneği, Doktora Tezi, Sakarya Üniversitesi Sosyal Bilimler Enstitüsü, Sakarya.

Özutku, H. (2008). Örgüte, Duygusal, Devamlılık ve Normatif Bağlıık Ile İş Performansı Arasındaki İlişkinin İncelenmesi, İstanbul Üniversitesi İşletme Fakültesi Dergisi, Cilt/Vol:37, Sayı:2, ss. 80.

Redford, K. (2005). Shedding light on talent tactics, Personnel Today, Sep 26th, ss.20.

Russo, D. F. (2010). 17 Rules Successful Companies Use to Attract and Keep Top Talent, USA: Pearson Education Inc.

Schermelleh-Engel, K., Moosbrugger, H., Müller, H. (2003). Evaluating the fit of structural equation models: Tests of significance and descriptive goodness-of-fit measures. Methods of psychological research online, 8(2), 23-74.

Schweyer, A. (2004). Talent Management Systems: Bestpractices In Technology Solutions For Recruitment, Rententionand Workforce Planning, Hoboken: HR.com.

Silzer, R., Bern, D. (2010). Strategy-Driven Talent Management, San Francisco: John Wiley \& Sons. 
Sivenco, A. (2008). Contemporary Leadership Challenges: Talented Organisation for Talented People. Kalmar: Yüksek Lisans www.researchgate.net/publication/279660018 Contemporary Leadership Challenges Tale nted Organisation for Talented People (Erisim: 19.05.2017).

Skuza, A.S.H., Mcdonnell, A. (2013). An Analysis of The Talent Management Challenges in A PostCommunist Country: The Case of Poland, The International Journal of Human Resource Management, 24 (3), ss.453-470.

Socpo, (2005). Talent management-The capacity to make a difference, The Society for Chief Personnel Officers/Veredus, London.

Song, J., Hong, M.K., Kolb, J.A. (2009). The effect of learning organization culture on the relationship between interpersonal trust and organizational commitment, Human Resource Development Quarterly, vol. 20, no. 2, ss.147-167.

Stalh, G., Ingmar, B., Elaine, F., Shad, M., Jaap, P., Philiph, S., Jonathan, T., Patrick, W. (2012). Six Principles of Effective Global Talent Management. MIT Sloan Management Review, 53, 2, ss. 25-32.

Stewart, J. (2008). Developing Through Talent Management, SSDA Catalyst, 6., pp.1-14.

Stone, M. (2002). Forgiveness in the workplace. Industrial and Commercial Training, 34(7), 278286.

Şahin, Ö. (2015). Yetenek Yönetimi ve Yenilik Performansı Iliş̧isi: Konaklama İşletmelerinde Bir Araştırma, Adnan Menderes Üniversitesi, SBE., Aydın.

Tabancalı, E., Şimşek, G.G., \& Korumaz, M. (2017). Talent management in educational organizations: a scale development study. European Journal of Education Studies. 3(10), ss.404-424.

Tanke, M. (1990). Human Resource Management For The Hospitality Industry, Pn ss.5 Delmar Publishers Inc.

Ulrıch, D., Michael, L., Gerry, L. (1997). Tomorrow's HR Management, John Wiley \& Sons Inc, USA.

Yazıcıoğlu, S. (2006). Yetenek Yönetiminde Bir Uygulama: Üst Düzey Yönetici Yedekleme Amaçlı Geliştirme Programı, Yüksek Lisans Tezi, Marmara Üniversitesi, SBE., İstanbul.

http://www.tdk.gov.tr (Erişim tarihi: 30.08.2017). 


\section{Yetenek Yönetimi Uygulamaları Ölçeği}

Size uygun ifadeyi 1,2,3,4, ve 5 olarak DEĞERLENDIRME hanesine yazınız

\begin{tabular}{|c|c|c|}
\hline \multirow{4}{*}{ 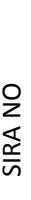 } & \multirow{4}{*}{ 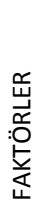 } & 1 Hiç Katılmıyorum \\
\hline & & 2 Katılmıyorum \\
\hline & & 3 Kararsızım/Ortadayım \\
\hline & & 4 Katılıyorum \\
\hline
\end{tabular}

ÖRGÜTÜM...

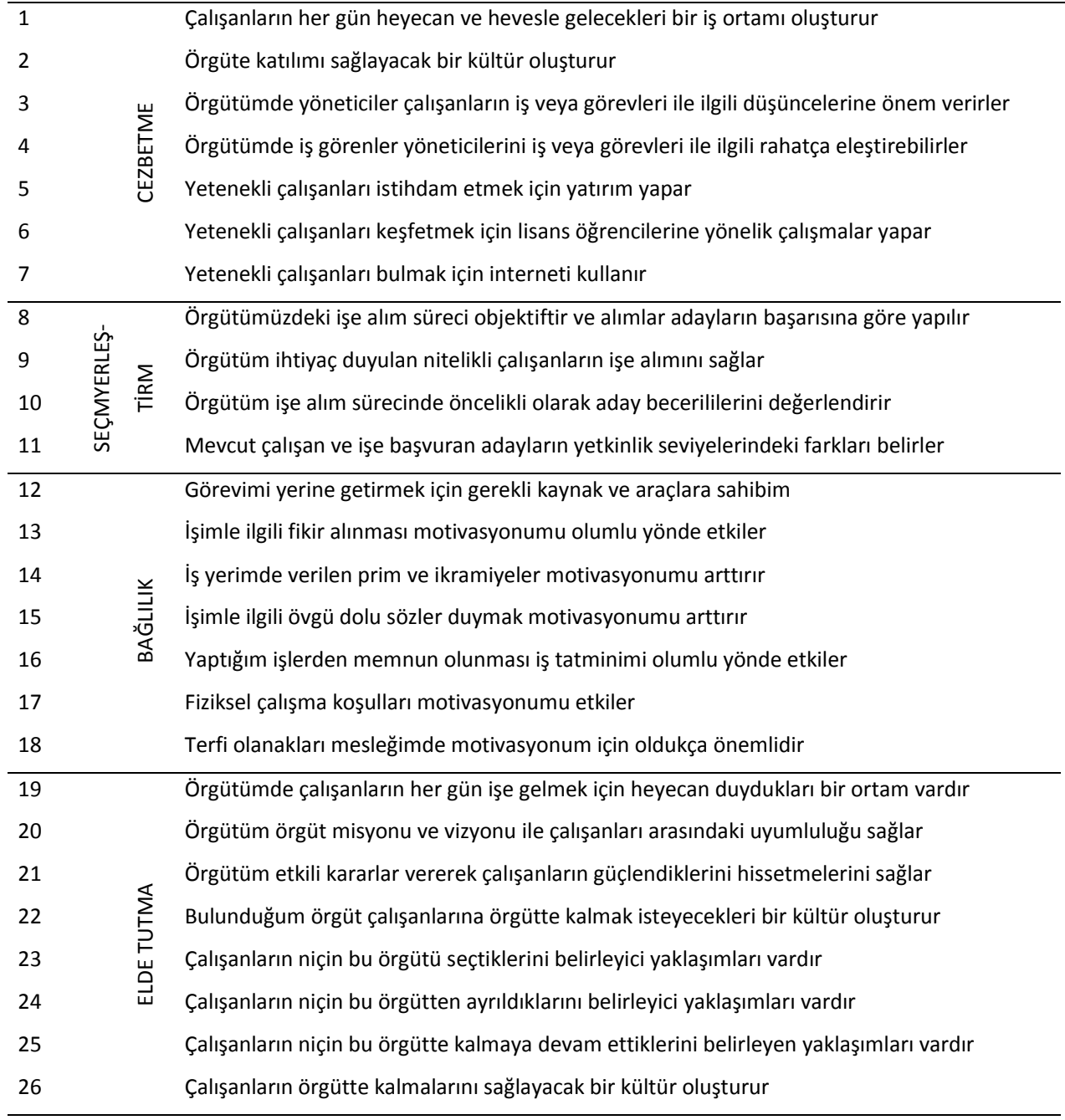




\section{Cengiz DURAN | Dursun BOZ | Sema BEHDiOĞLU | Songül KUTLU}

\begin{tabular}{|c|c|c|}
\hline 27 & \multirow{8}{*}{ 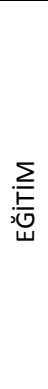 } & Örgütüm mevcut çalışanlara işlerini iyi yapmalarını sağlayacak yeterli eğitimleri sağlar \\
\hline & & Örgütüm kişisel gelişim hedefli eğitim (dil, liderlik, etkin iletişim, ekip çalışması, proje yönetimi, \\
\hline 28 & & vs.) uygulamaları yapar \\
\hline 29 & & Teknik alanlarda ve uzmanlık konularında gelişimi hedefleyen eğitim uygulamaları yapılır \\
\hline 30 & & Yeni işe alınanlar için yetenek yönetimi girişimleri ile oryantasyon sürecini birlikte uygular \\
\hline 31 & & Çalışanları işletmenin vizyonu ve misyonu ile uyumlu hale getirir \\
\hline 32 & & Lider geliştirme programlarını uygulamaktadır \\
\hline 33 & & Kariyer gelişim fırsatlarını destekleyen politikalar yaratır \\
\hline 34 & \multirow{11}{*}{ 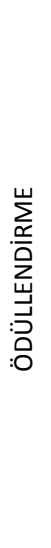 } & İşimi en iyi şekilde yapmam yöneticilerimden takdir almamı sağlar \\
\hline 35 & & İşimi en iyi şekilde yapmam maaşıma zam almamı sağlar \\
\hline 36 & & İşimi en iyi şekilde yapmam terfi etmeme yol açar \\
\hline 37 & & Genel olarak bu işletmenin ekstra çaba harcayan çalışanlarını ödüllendirdiğine inanıyorum \\
\hline 38 & & Çalıştığım yerde ödüller çalışana adil olarak verilmektedir \\
\hline 39 & & Yaptığım iş benim açımdan tatmin kaynağı olduğu için ödül beklentisi içinde olmamaktayım \\
\hline 40 & & Çalıştığım yerde ödüllendirme kriterleri iş görenlere açıkça aktarılmaktadır \\
\hline 41 & & İş yerimde genellikle maddi nitelikte ödüller verilmektedir \\
\hline 42 & & İş yerimde genellikle manevi nitelikte ödüller verilmektedir \\
\hline 43 & & İş yerinde aldığımız ödüllere ilişkin fikirlerimizi yöneticilerimizle rahatlıkla paylaşabiliriz \\
\hline 44 & & Mevcut çalışanlara iş için gerekli becerilerinden dolayı ücret ayarlamaları sağlar \\
\hline 45 & \multirow{5}{*}{ 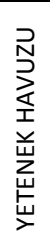 } & Her düzeyde çalışan için daha geniş havuzlar oluşturur \\
\hline 46 & & Örgütün büyüyüp genişlemesini sağlayacak elemanların alımı için zemin oluşturur \\
\hline 47 & & Her seviyedeki çalışanlar için yedek havuzunu oluşturur \\
\hline 48 & & İşletme büyüyüp geliştikçe yaratılacak boş pozisyonları belirler \\
\hline 49 & & Mevcut olan çalışan ve aday yetenek düzeylerindeki boşlukları tanımlar \\
\hline
\end{tabular}




\section{TALENT MANAGEMENT APPLICATIONS SCALE}

Answer these questions by suitable number 1,2,3,4 and 5 on evaluation column

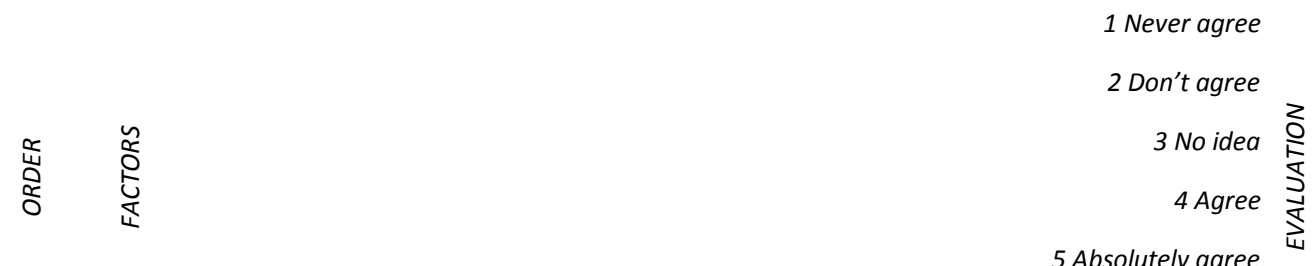

MY ORGANIZATION...

\begin{tabular}{|c|c|c|}
\hline 1 & \multirow{7}{*}{ 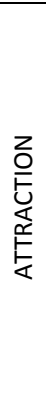 } & Creates a work environment where employees are excited and enthusiastic every day \\
\hline 2 & & It creates a culture that will enable participation in the organization \\
\hline 3 & & In my organization, managers care about employees' thoughts about their jobs or duties. \\
\hline 4 & & $\begin{array}{l}\text { Employees in my organization can criticize their managers comfortably about their work or } \\
\text { duties. }\end{array}$ \\
\hline 5 & & It invests in employing talented employees. \\
\hline 6 & & It conducts studies for undergraduate students in order to discover talented employees \\
\hline 7 & & Uses the internet to find talented employees \\
\hline 8 & \multirow{4}{*}{ 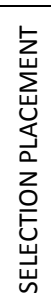 } & $\begin{array}{l}\text { The recruitment process in our organization is objective and recruitments are made according } \\
\text { to the success of the candidates }\end{array}$ \\
\hline 9 & & My organization ensures recruitment of qualified employees by needs \\
\hline 10 & & My organization evaluates candidate skills in the recruitment process \\
\hline 11 & & $\begin{array}{l}\text { Identifies the differences in the competence levels of the present employees and candidates } \\
\text { applying for employment }\end{array}$ \\
\hline 12 & \multirow{7}{*}{ 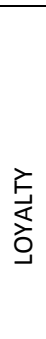 } & I have the resources and tools to fulfill my duty \\
\hline 13 & & Getting ideas about my job positively affects my motivation \\
\hline 14 & & The premium and bounties in the job increase my motivation \\
\hline 15 & & Hearing words with full of praise about my job increase my motivation \\
\hline 16 & & Being contented about my works positively affect my job satisfaction \\
\hline 17 & & Physical working conditions affect my motivation \\
\hline 18 & & Promotion opportunities are very important for my motivation in my profession \\
\hline
\end{tabular}




\section{Cengiz DURAN | Dursun BOZ | Sema BEHDiOĞLU | Songül KUTLU}

\begin{tabular}{|c|c|c|}
\hline 19 & \multirow{8}{*}{ 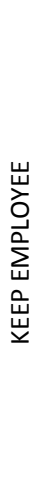 } & My organization has an environment where employees are excited to come to work everyday \\
\hline 20 & & $\begin{array}{l}\text { My organization provides the compatibility between the mission and vision of the organization } \\
\text { and its employees }\end{array}$ \\
\hline 21 & & $\begin{array}{l}\text { My organization make provide feeling empowerment of employees by making effective deci- } \\
\text { sions }\end{array}$ \\
\hline 22 & & My organization creates a culture where employees want to stay in the organization \\
\hline 23 & & There are determinants of why employees choose this organization \\
\hline 24 & & There are determinants of why employees are separated from this organization \\
\hline 25 & & There are approaches that determine why employees continue to stay in this organization \\
\hline \multirow[t]{2}{*}{26} & & It creates a culture that will enable employees to stay in the organization \\
\hline & \multirow{7}{*}{ 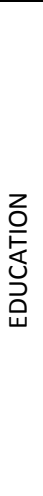 } & $\begin{array}{l}\text { My organization provides adequate training to present employees to ensure they do their jobs } \\
\text { well }\end{array}$ \\
\hline 28 & & $\begin{array}{l}\text { My organization conducts personal development-oriented training (language, leadership, } \\
\text { effective communication, teamwork, project management, etc.) }\end{array}$ \\
\hline 29 & & $\begin{array}{l}\text { Applications of training carry out by aiming at development in technical fields and specialization } \\
\text { topics }\end{array}$ \\
\hline 30 & & Applies talent management initiatives and orientation process for new hires \\
\hline 31 & & It aligns employees with the vision and mission of the enterprise \\
\hline 32 & & It carry out programs of leader developing \\
\hline 33 & & It create policies which support opportunities of career development \\
\hline 34 & \multirow{11}{*}{ 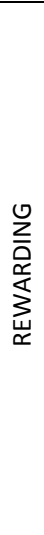 } & Doing my job by best way provide getting appreciation from managers \\
\hline 35 & & Doing my job by best way provide getting salary raise \\
\hline 36 & & Doing my job best way causes getting promotion \\
\hline 37 & & In general, I believe this business has rewarded its employees with extra effort \\
\hline 38 & & Where I work, the awards are given to the employee fairly \\
\hline 39 & & I am not expecting reward because my work is a source of satisfaction for me \\
\hline 40 & & Where I work, the award criteria are clearly communicated to those who work \\
\hline 41 & & In my workplace, material awards are usually given \\
\hline 42 & & My workplace is usually given spiritual awards \\
\hline 43 & & We can share our ideas about the awards we receive at the workplace with our managers \\
\hline 44 & & It provides wage adjustments to existing employees due to the skills required for the job \\
\hline 45 & \multirow{3}{*}{ 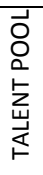 } & Creates wider pools for each level worker \\
\hline 46 & & It forms the basis for the recruitment of elements that will allow the organization to grow and expand \\
\hline 47 & & Creates a backup pool for employees of all levels \\
\hline
\end{tabular}




\section{Eskişehir Osmangazi Üniversitesi Sosyal Bilimler Dergisi}

